\title{
Considerations for Medications Commonly Utilized in the Oncology Population in the Intensive Care Unit
}

\author{
Anne Rain Tanner Brown, Michelle Horng, and \\ Terri Lynn Shigle
}

\section{Contents}

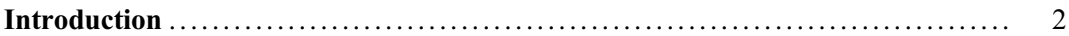

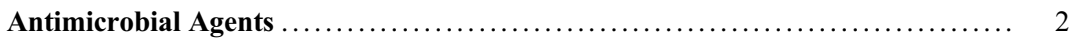

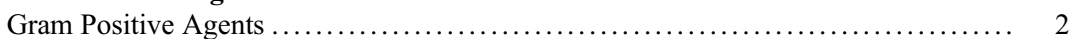

Gram Negative Agents ............................................ 3

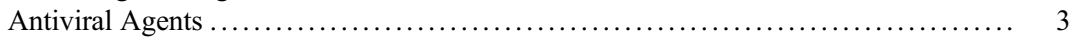

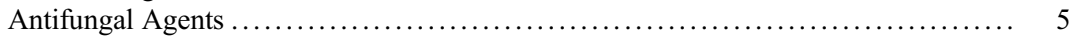

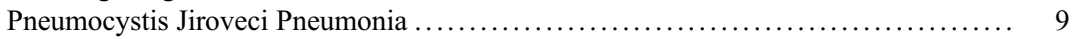

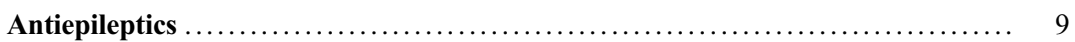

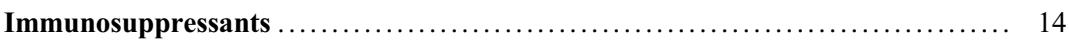

Antifibrinolytic/Antihemophilic Agents .............................. 14

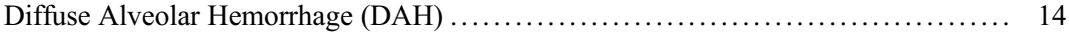

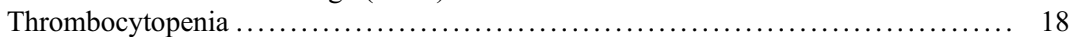

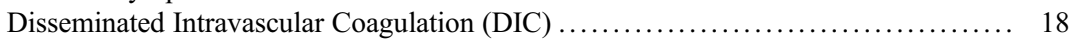

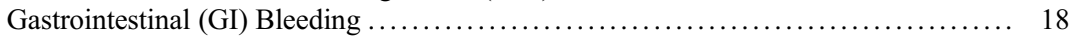

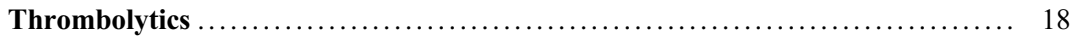

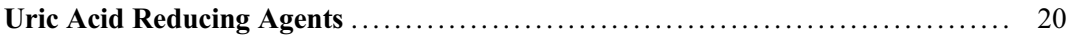

Hypercalcemia of Malignancy/Hypercalcemia Management $\ldots \ldots \ldots \ldots \ldots \ldots \ldots .20$

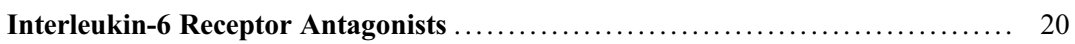

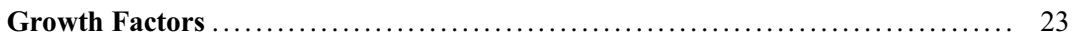

\footnotetext{
A. R. T. Brown $(\bowtie) \cdot$ M. Horng

Clinical Pharmacy Specialist - Critical Care/Nutrition

Support, The University of Texas MD Anderson Cancer

Center, Houston, TX, USA

e-mail: artanner@mdanderson.org;

mhorng1@mdanderson.org

T. L. Shigle

Clinical Pharmacy Specialist - Oncology, The University of Texas MD Anderson Cancer Center, Houston, TX, USA e-mail: tshigle@mdanderson.org
}

(C) This is a U.S. Government work and not under copyright protection in the US; foreign copyright protection may apply 2019 
Antidotes

References .

\section{Abstract}

An increasing number of oncologic patients are presenting to the intensive care unit with complications from both their chronic disease states and cancer therapies due to improved survival rates. The management of these patients is complex due to immunosuppression (from the malignancy and/or treatment), metabolic complications, and diverse medication regimens with the potential for significant drug-drug interactions and overlapping adverse effects. This chapter will provide clinicians with an overview of non-chemotherapy medications frequently encountered in the critically ill oncologic patient, with a focus on practical considerations.

\section{Keywords}

Oncology $\cdot$ Critical care $\cdot$ Cancer $\cdot$ Drug interactions $\cdot$ Pharmacology $\cdot$ Intensive care $\cdot$ Critically ill $\cdot$ Drug monitoring $\cdot$ Adverse events $\cdot$ Immunocompromised

\section{Introduction}

As advances in cancer therapies continue to improve, a growing number of patients are living with cancer. As such, there is an increased probability for critical care providers to encounter cancer patients within the intensive care unit (ICU). Furthermore, oncologic patients require increased utilization of resources in the ICU due to diseaserelated complications and/or treatment-related adverse events [124]. Metabolic complications present difficult challenges in the management of critically ill cancer patients [72]. Immunosuppression, secondary to the cancer itself or cancerrelated therapies (e.g., chemotherapy, corticosteroids, hematopoietic cell transplant, etc.), places patients at an increased risk for infection. In addition, many new chemotherapy and targeted therapies have numerous adverse effects that not only increase the risk for ICU admission but require multiple other therapies to help manage these side effects.

Medication regimens for critically ill cancer patients are complex. Many patients require a large number of concomitant medications to manage the critical, oncologic, and supportive care issues encountered. Accordingly, avoidance and detection of drug-drug interactions and overlapping adverse effect profiles is of high concern. The intent of this chapter is to provide critical care practitioners with an overview of non-chemotherapy medications that are frequently encountered during the care of a critically ill cancer patient in hopes of increasing awareness of such therapy. It should be emphasized that this chapter is not all-inclusive in respect to the medications discussed and details provided, and clinicians are advised to seek additional information as applicable. In addition, medication doses are reflective of a patient with normal renal function and clinicians should refer to drug dosing references for organ dysfunction adjustments unless otherwise noted.

\section{Antimicrobial Agents}

\section{Gram Positive Agents}

Risk for methicillin resistant staphylococcus aureus (MRSA) and vancomycin resistant enterococcus (VRE) as shown in Table 1 may be heightened in the oncology population due to increased exposure to the healthcare setting and antimicrobials [11]. While initial therapy of patients with febrile neutropenia may not require coverage for MRSA, empiric antibiotic regimens for all patients progressing to sepsis or septic shock or those patients with additional risk factors should be broadened to include an agent targeting aerobic gram positive cocci [102]. For MRSA, consider early addition of vancomycin, linezolid, 
Table 1 Considerations for MRSA/VRE coverage

\begin{tabular}{l|l}
\hline MRSA & VRE \\
\hline Vascular access devices & Previous VRE infection \\
\hline Gram positive bacteremia prior to speciation & High rates of hospital endemicity \\
\hline Known colonization or prior infection with MRSA & Known colonization \\
\hline Clinical instability (hypotension or shock) & \\
\hline Skin or soft tissue infection & \\
\hline Pneumonia requiring ICU admission & \\
\hline Penicillin resistant Streptococcus pneumoniae & \\
\hline High rates of hospital endemicity & \\
\hline Severe mucositis if FQ prophylaxis + ceftazidime is employed as empiric therapy & \\
\hline $\begin{array}{l}\text { MRSA methicillin resistant staphylococcus aureus, } V R E \text { vancomycin resistant enterococcus, ICU intensive care unit, FQ } \\
\text { fluoroquinolone } \\
\text { Adapted from [11, 43] }\end{array}$
\end{tabular}

or daptomycin. For VRE, consider early addition of linezolid or daptomycin. Selection of a specific agent should be based on patient-specific (e.g., end organ function) as well as an infectionspecific factors (e.g., source of infection). As mentioned in Table 2, use of linezolid may compromise bone marrow function; this does not preclude use of linezolid in patients with pancytopenia or thrombocytopenia, but it does justify a risk-benefit analysis inclusive of alternative options prior to therapy initiation [126]. Consider an infectious diseases (ID) consult if MRSA or VRE is isolated in the context of systemic infection [11, 43]. Discontinuation of MRSA and/or VRE therapy should be considered if a pathogen is not identified within $48-72 \mathrm{~h}$ of obtaining all pertinent cultures.

\section{Gram Negative Agents}

Empiric intravenous (IV) antibiotics with antipseudomonal coverage should be initiated immediately in high-risk patients with febrile neutropenia and may include piperacillin/tazobactam, ceftazidime, cefepime, meropenem, or imipenemcilastatin [11, 43]. Unfortunately, frequent exposure to antimicrobials and repeated hospitalization result in greater risk of acquiring resistant gramnegative organisms [114].

Oncology patients are at increased risk of infections with gram negative organisms from translocation from the gastrointestinal (GI) tract, particularly in patients with mucositis or graft versus host disease (GVHD). Risk of acquiring multi-drug resistant (MDR) gram negative organisms is increased by the use of prophylactic fluoroquinolones in patients with chemotherapyinduced neutropenia [33, 71, 78]. Initial empiric coverage of extended spectrum beta lactamase (ESBL) organisms and carbapenem resistant enterobacteraciae (CRE) should be based on patient-specific factors including prior exposure of antipseudomonal prophylaxis for febrile neutropenia patients and prior infections or microbiologic culture results. Double antipseudomonal gram-negative coverage may be warranted in patients with a history of $P$. aeruginosa or other MDR organism colonization or in hemodynamically unstable patients. Combination therapy with an aminoglycoside should be preferred in patients recently treated with fluoroquinolone prophylaxis (Table 2) [11]. Consider an infectious disease consult for patients with multidrug resistant organisms (MDRO).

\section{Antiviral Agents}

Oncology patients, particularly those with hematologic malignancy and/or history of HCT, are at risk for viral infections as a result of their underlying malignancy, chemotherapy, prolonged neutropenia, impaired cell-mediated immunity, and/or treatment complications (e.g., GVHD) [136]. Infection with herpes simplex (HSV), herpes zoster (HZ), cytomegalovirus (CMV), and respiratory viruses (e.g., respiratory syncytial 


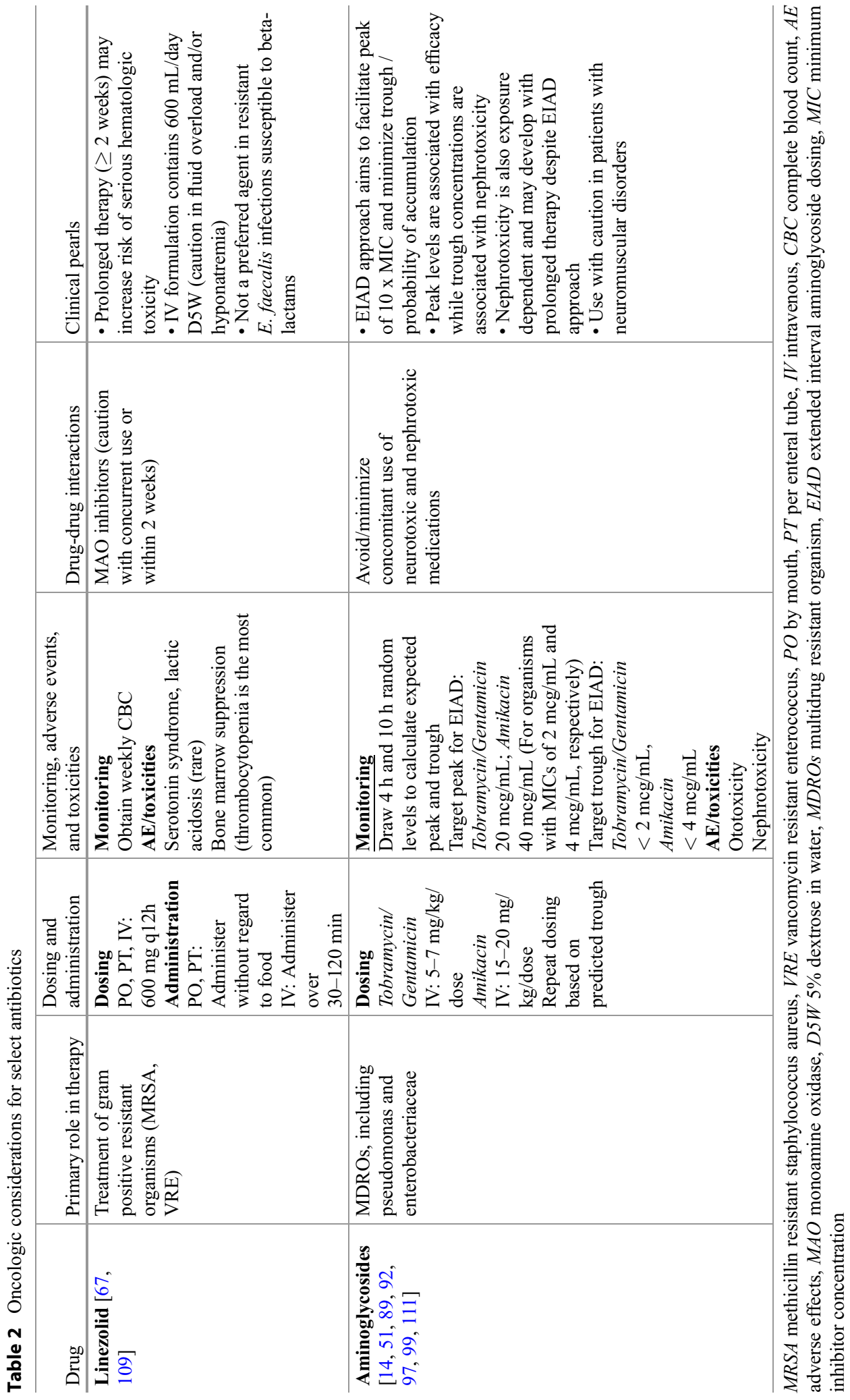


virus [RSV]) are of prominent concern. A review of the pharmacologic options for management of these infections is presented in Table 3.

Many oncology patients admitted in the ICU may already be receiving antiviral prophylaxis against herpes simplex virus (HSV) and herpes zoster (HZ) with acyclovir or valacyclovir. In addition to $\mathrm{HSV} / \mathrm{HZ}$, another common pathogen observed in patients with hematologic malignancy/post-HCT is cytomegalovirus (CMV). CMV is a beta herpes virus with a sero-prevalence in the United States (US) of around $60 \%$ [130]. Typically, most people are asymptomatic when primary infection with CMV occurs and then the virus enters a latent infectious state in mononuclear leukocytes. Reactivation can occur in many instances, but in relation to the oncology patient population, this can be seen during times of immunosuppression (e.g., chemotherapy administration) and critical illness as well as in the elderly [34]. Prophylaxis against $\mathrm{CMV}$ is not routine, given the toxicity profile of traditional anti-CMV therapy (i.e., ganciclovir and foscarnet); rather a strategy of pre-emptive monitoring has been adopted with treatment reserved for patients with presumed or documented infection [136]. Recently, the Federal Drug Agency (FDA) approved letermovir for CMV prophylaxis in HCT CMV seropositive recipients. Given the more acceptable toxicity profile of this agent and the morbidity/mortality associated with CMV infection, use of letermovir will likely increase in hopes of preventing CMV reactivation [84].

Despite preventive strategies and increased awareness, respiratory viral infections may occur, with RSV, influenza, parainfluenza, and human metapneumovirus responsible for the majority of cases. Progression to lower respiratory tract infection often presents as dyspnea and hypoxia, which can prove fatal. Unfortunately, limited options currently exist for managing these viral infections (e.g., neuraminidase inhibitors for influenza, ribavirin for RSV) and therapy is primarily supportive. Studies are needed to further elucidate high-risk patients and determine efficacy of novel antiviral agents [23]. Other viruses that may be notable for complications in cancer patients include adenovirus, human herpesvirus 6 (HHV6), polyomaviruses (BK and JC), and Epstein-Barr virus (EBV).

\section{Antifungal Agents}

Antifungal coverage should be considered in febrile neutropenic patients on broad-spectrum antibiotics who have had a persistent fever for 4-7 days and no identified fever source [43]. Antifungal therapy should also be considered in critically ill ICU patients (regardless of the presence or absence of malignancy) with suspected infection who do not improve after $72 \mathrm{~h}$ of broad-spectrum antibiotics [110]. For empiric coverage of Candida, use of an echinocandin (anidulafungin, micafungin, or caspofungin) is preferred, especially in patients who have been recently treated with other antifungal agents, or if Candida glabrata or Candida krusei is suspected from previous culture data $[47,114]$.

Hematologic malignancy patients with prolonged neutropenia, status post allogeneic HCT, and/or chronic corticosteroid exposure (e.g., GVHD) are at risk for invasive aspergillosis infections [101]. Posaconazole or voriconazole are often utilized for prophylaxis against invasive aspergillosis in high-risk patients [29, 139, 146]. In the absence of contraindications (i.e., organ dysfunction, adverse effects) or development of a breakthrough infection, antifungal prophylactic regimens should be continued following ICU admission. For patients who develop breakthrough invasive aspergillosis while receiving prophylactic azole therapy, therapeutic drug monitoring (TDM) should be performed to assess adequacy of the current regimen, if available; however, the patient will likely need to be switched to another class of medications. Voriconazole remains the treatment of choice for Aspergillus infections (Table 4). However, if the patient is unable to tolerate voriconazole therapy, isavuconazonium or the liposomal formulation of Amphotericin B (AmB) are appropriate alternative options for initial therapy. Posaconazole can be considered for salvage therapy [101]. 


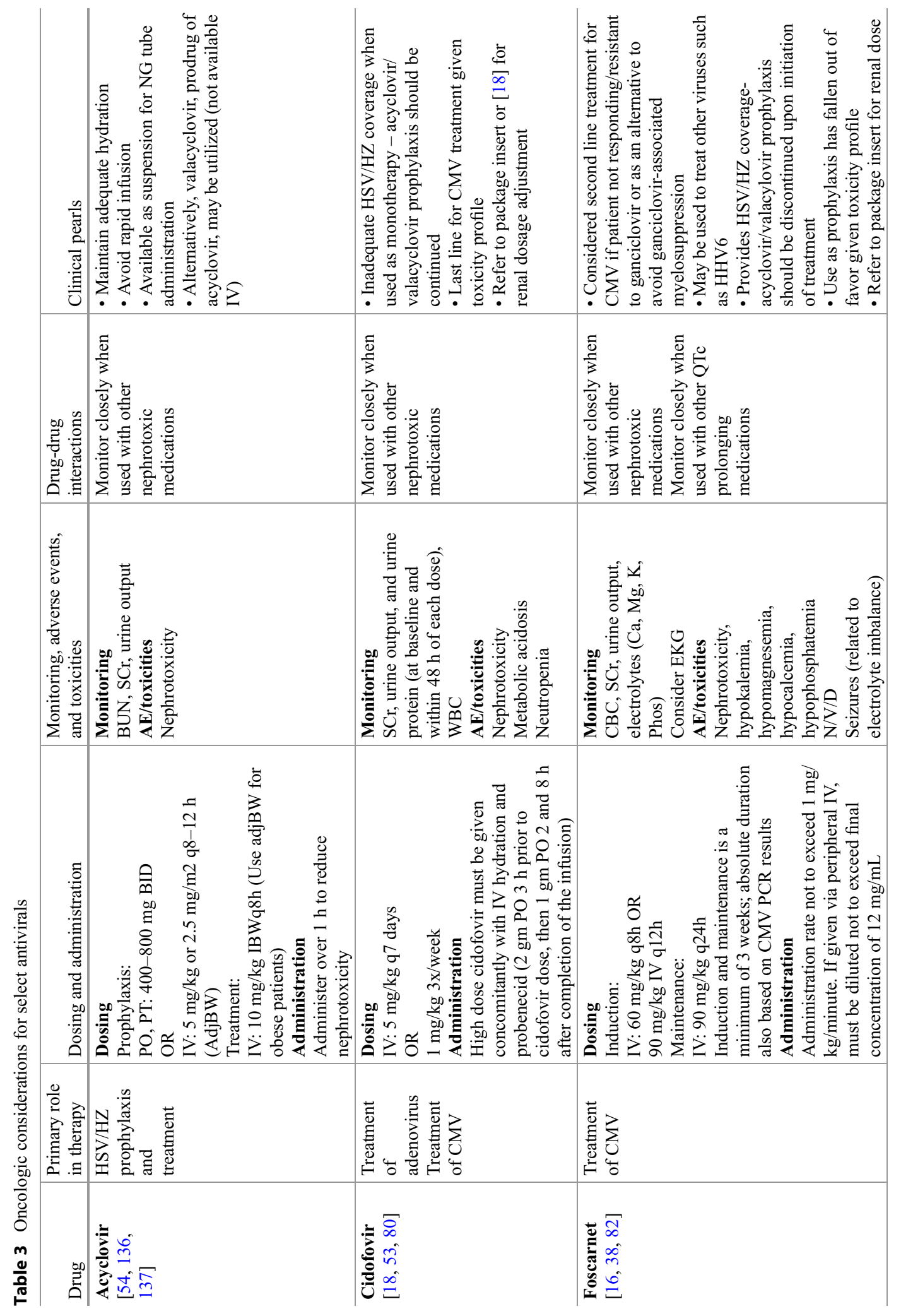




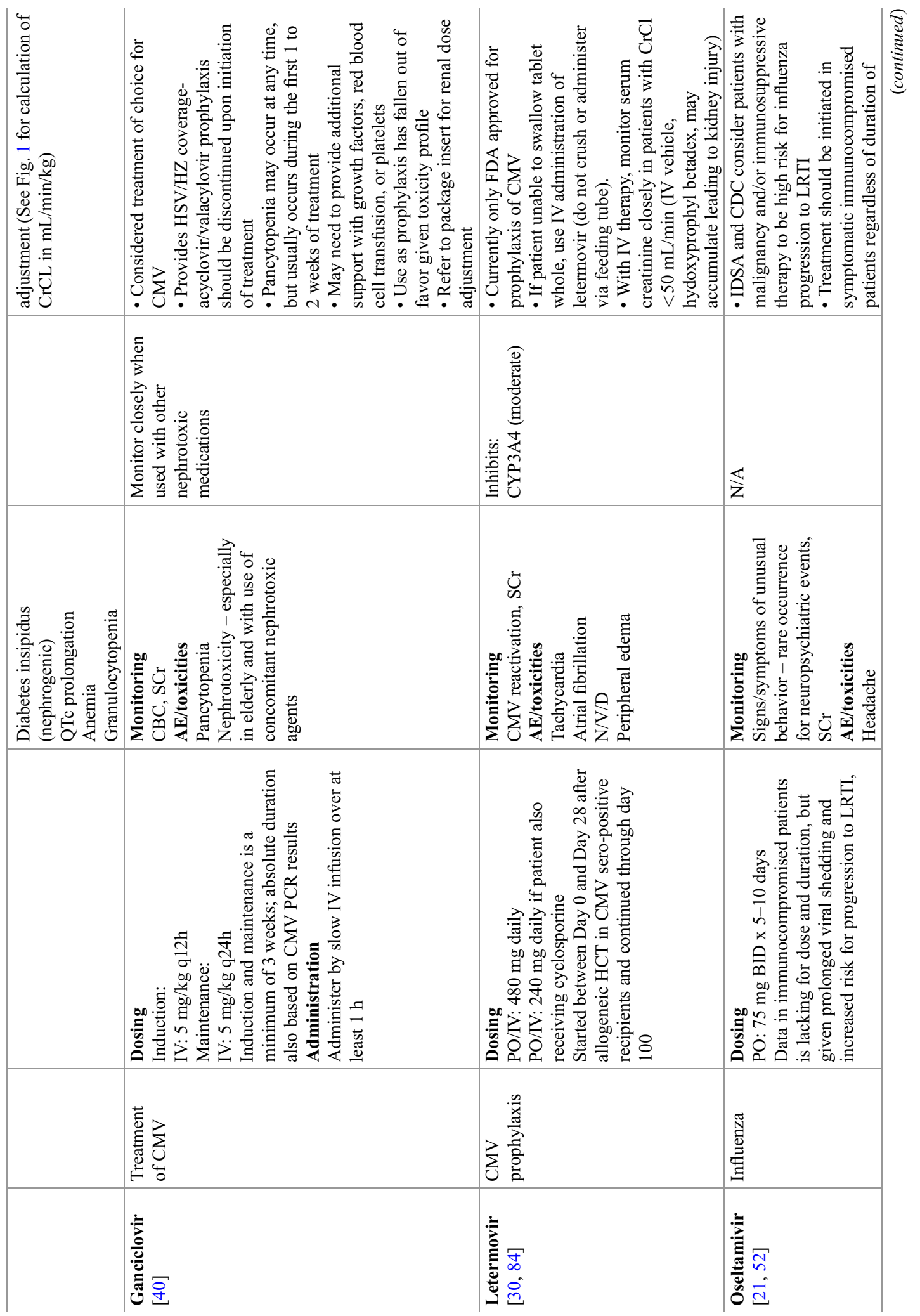




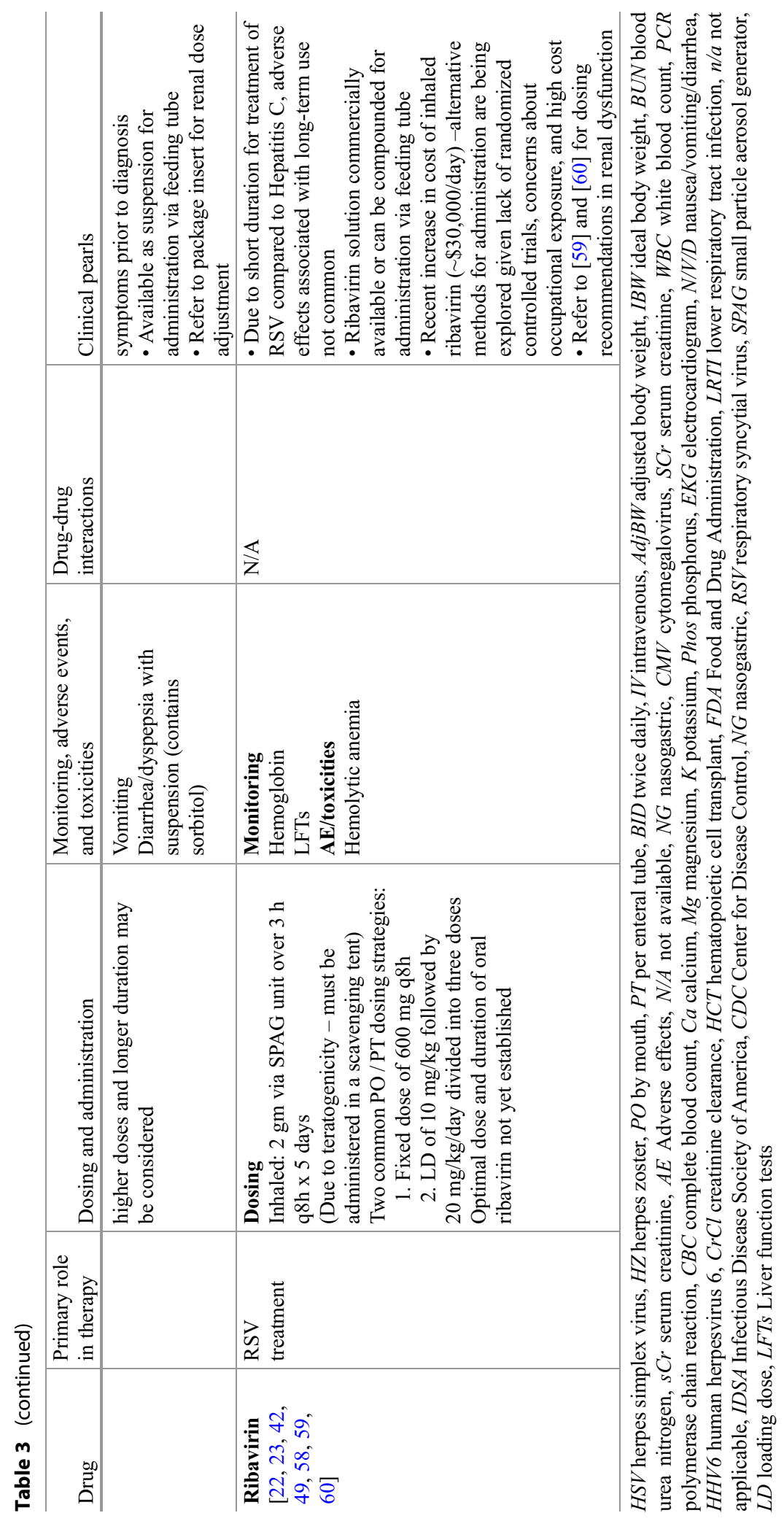


$((140 \mathrm{mg}-$ age $) /($ serum creatinine $\mathrm{x} 72))(\mathrm{x} 0.85$ for females $)=\mathrm{mL} / \mathrm{min} / \mathrm{kg}$

Fig. 1 How to calculate CrCL as $\mathrm{mL} / \mathrm{min} / \mathrm{kg}$ with modified Cockcroft and Gault equation for Foscarnet dosing. (Reference: (1) Foscarnet package insert)

Severe and prolonged immunosuppression also places patients at risk for mucormycosis infections. Posaconazole has been shown to be the most effective antifungal for prophylaxis against mucormycosis; of note, voriconazole is not active against mucormycosis. Liposomal $\mathrm{AmB}$ is recommended by the guidelines as the treatment of choice for mucormycosis infections; however, isavuconazonium has recently been approved with the indication as well [10]. Posaconazole is reserved for salvage therapy. Surgical interventions combined with medical treatments have been associated with higher survival rates in patients with mucormycosis when compared to pharmacologic therapy alone [28].

Cancer patients are commonly on numerous medications and chemotherapies that may interact with concomitant azole therapy. Azoles are potent inhibitors and substrates of cytochrome p450 enzymes; therefore, clinicians must be diligent about evaluating for drug-drug interactions (DDIs). In addition, azoles can cause QTc prolongation. Clinicians should monitor closely and optimize electrolytes, particularly in patients on multiple QTc prolonging medications.

\section{Pneumocystis Jiroveci Pneumonia}

Prophylaxis and treatment for pneumocystis jiroveci pneumonia (PJP) should be considered in patients with risk factors (neutropenic, immunosuppressed, long-term or high-dose steroids) who are not improving on standard antimicrobial therapy. Prophylactic therapy is usually given to oncologic patients receiving certain types of chemotherapy (i.e., alemtuzumab, purine analogs), HCT patients, or patients on immunosuppression with chronic and/or high-dose steroids. The choice of prophylaxis (e.g., sulfamethoxazole-trimethoprim

[SMZ-TMP], pentamidine) is typically based on patientand/or disease-specific factors (Table 5). Prophylaxis is usually continued until immunosuppression therapy has been discontinued and counts have recovered (absolute neutrophil count [ANC] $>1000$ ), CD4 $>200$, or according to the specific chemotherapy regimens as noted on the package insert or protocol [32].

For treatment of PJP infection, sulfamethoxazole-trimethoprim (SMZ-TMP) remains the drug of choice (Table 5). However, certain circumstances preclude use of SMZ-TMP, such as an allergy to sulfa medications, the desire to avoid agents that may suppress the bone marrow (e.g., HCT patients pre-engraftment), or persistent SMZ-TMP-related hyperkalemia. In such situations, alternative agents such as clindamycin/ primaquine should be considered.

\section{Antiepileptics}

Seizures are a common neurologic complication in oncologic patients, secondary to primary brain tumors, metastases, radiation toxicity, and metabolic abnormalities [57]. Selection of an antiepileptic drug (AED) warrants special consideration in the oncologic patient due to interactions with chemotherapy, side effects, and unique mechanisms of certain brain tumors. Enzyme inducing anticonvulsants such as phenytoin may lead to insufficient serum levels of concomitantly administered chemotherapy. Conversely, enzyme inhibiting anticonvulsants such as valproate may lead to toxic levels of chemotherapy [17]. AEDs that are substrates for P-gp (phenobarbital, carbamazepine, lamotrigine, topiramate, and felbamate) may result in insufficient intraparenchemal levels [88].

Patients with brain tumors are more prone to refractory epilepsy, requiring the use of multiple AEDs with different mechanisms. With the 


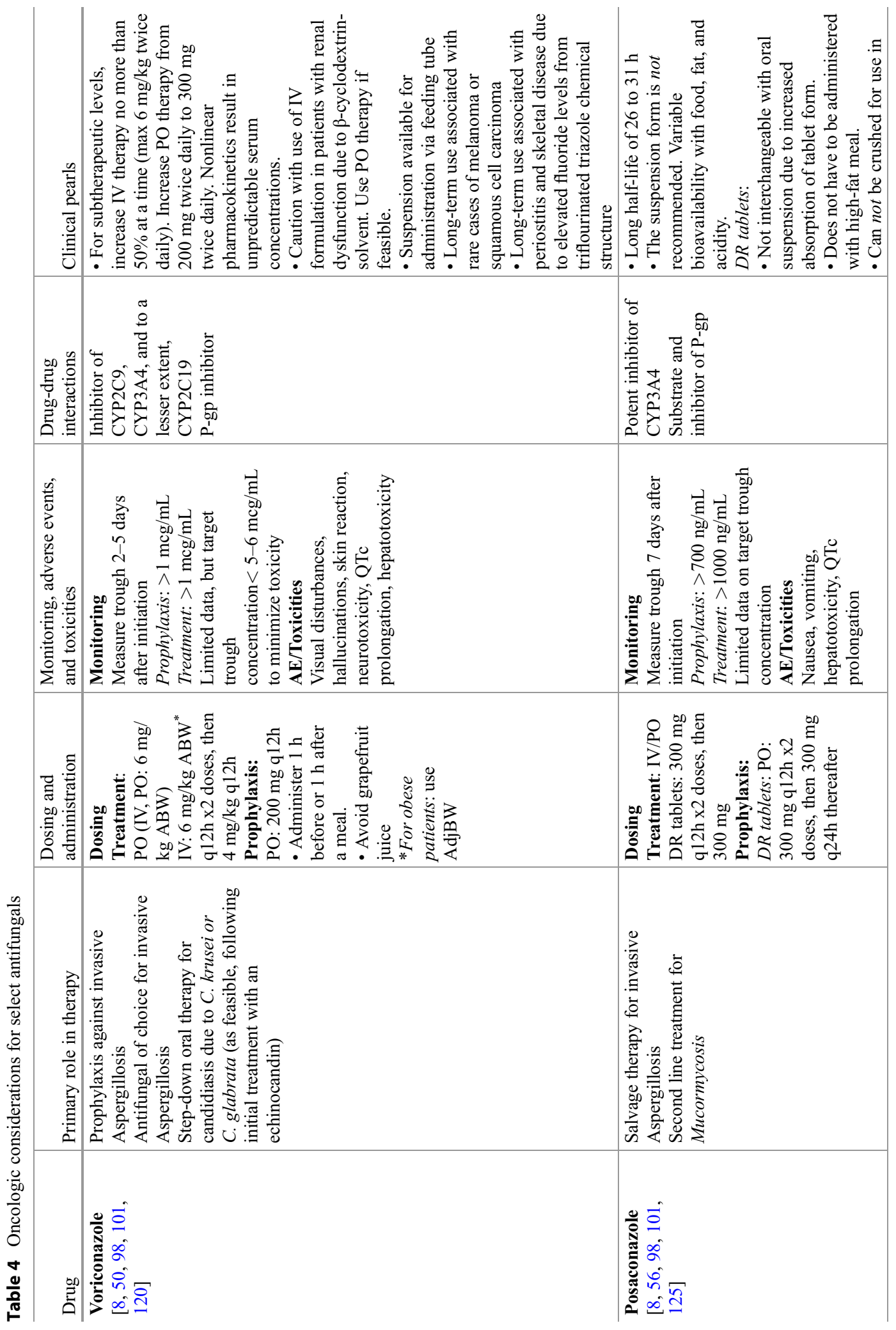




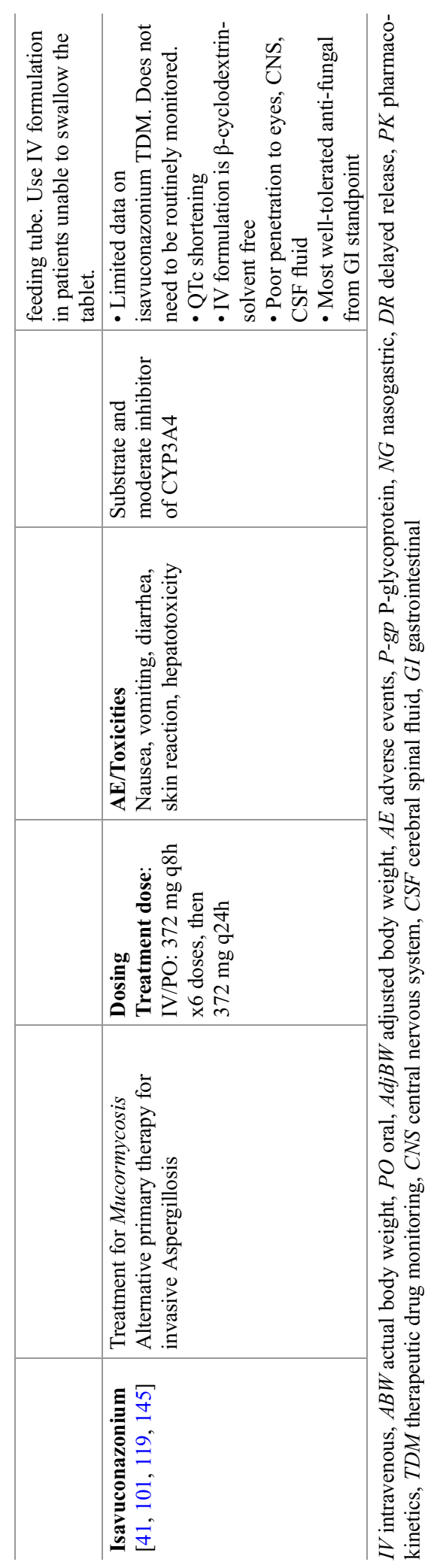




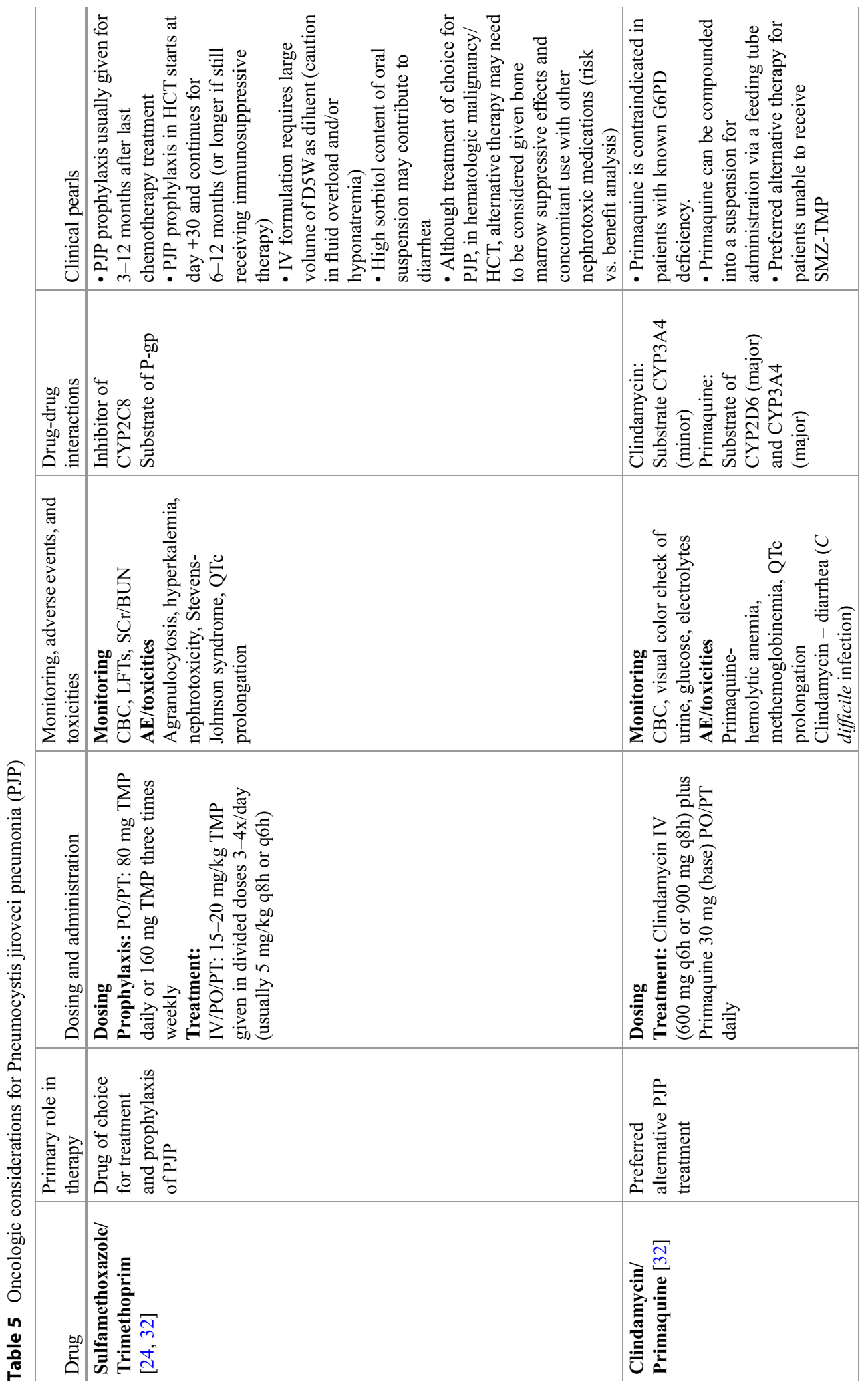




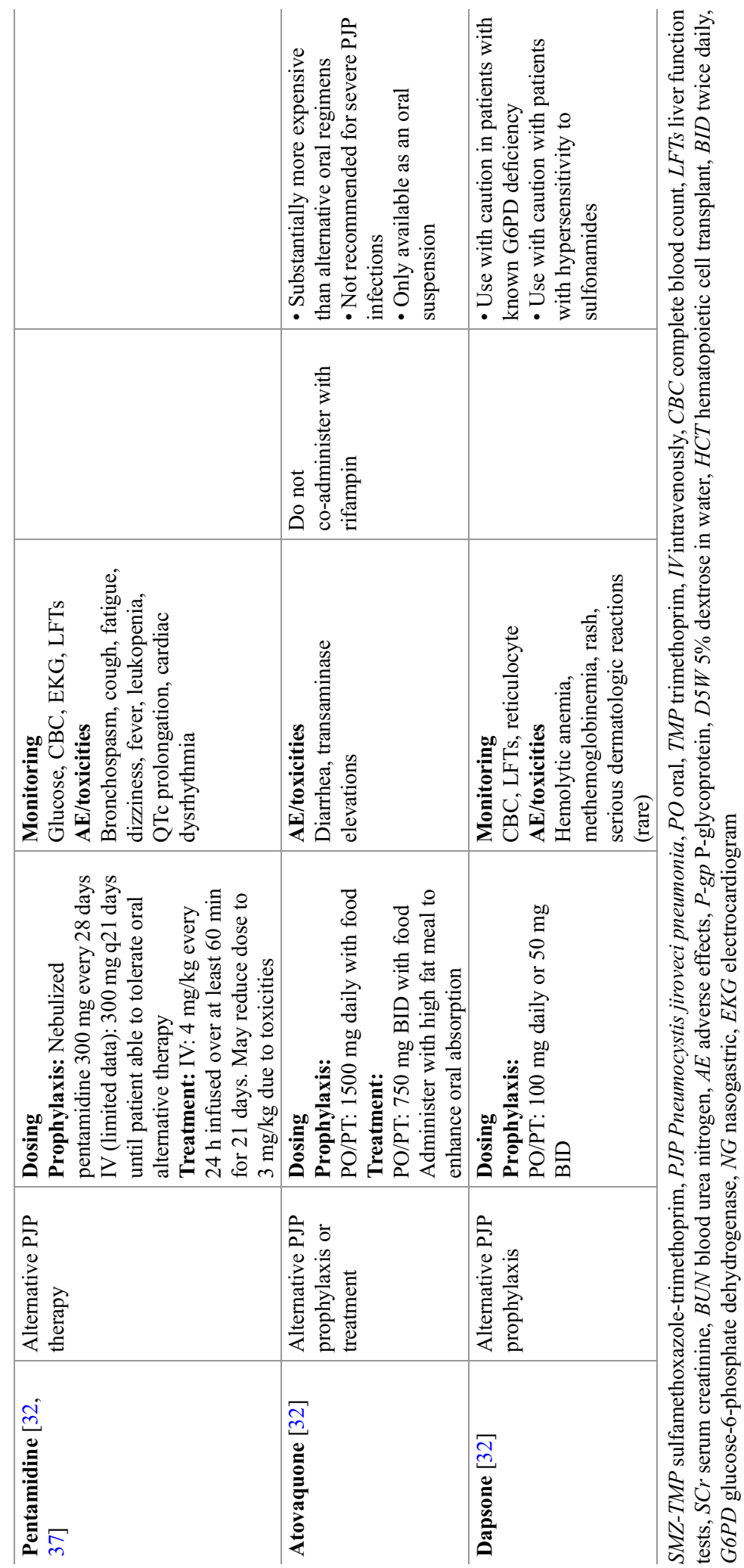


Table 6 Oncologic considerations for seizures

\begin{tabular}{|c|c|c|c|c|c|}
\hline Drug & $\begin{array}{l}\text { Primary role } \\
\text { in therapy }\end{array}$ & $\begin{array}{l}\text { Dosing and } \\
\text { administration }\end{array}$ & $\begin{array}{l}\text { Monitoring, adverse } \\
\text { events, and toxicities }\end{array}$ & $\begin{array}{l}\text { Drug-drug } \\
\text { interactions }\end{array}$ & Clinical pearls \\
\hline $\begin{array}{l}\text { Levetiracetam } \\
{[19,138]}\end{array}$ & $\begin{array}{l}\text { Prophylaxis } \\
\text { or treatment } \\
\text { of seizures }\end{array}$ & $\begin{array}{l}\text { Dosing } \\
\text { IV or PO/PT } \\
\text { (immediate } \\
\text { release tablet): } \\
1000-3000 \mathrm{mg} / \\
\text { day, divided } \\
\text { doses q12h } \\
\text { *max } 4500 \mathrm{mg} / \\
\text { day } \\
\text { PO/PT: } \\
\text { administer } \\
\text { without regard } \\
\text { to food } \\
\text { Administration } \\
\text { IV: } 15 \mathrm{~min} \text {, for } \\
\mathrm{SE}, \mathrm{max} \\
\text { 2-5 mg/kg/min }\end{array}$ & $\begin{array}{l}\text { AE/toxicities } \\
\text { CNS depression, toxic } \\
\text { epidermal necrolysis, } \\
\text { Stevens-Johnson } \\
\text { syndrome, and } \\
\text { aggression }\end{array}$ & & $\begin{array}{l}\text { - Dosing may be } \\
\text { limited by } \\
\text { somnolence } \\
\text { - Prophylaxis may } \\
\text { be warranted in } \\
\text { patients receiving } \\
\text { CAR T-cell therapy }\end{array}$ \\
\hline
\end{tabular}

$I V$ intravenously, $P O$ oral, $S E$ status epilepticus, $A E$ adverse events, $C N S$ central nervous system, $C A R$ chimeric antigen receptor

introduction of more well-tolerated AEDs, many practitioners are avoiding enzyme inducers as first-line agents [88]. While non-CYP-450 enzyme-inducing AEDs such as levetiracetam, gabapentin, and lamotrigine may be preferable in cancer patients receiving chemotherapy, levetiracetam may be preferred as an initial option in the ICU as it is available for IV administration, does not appear to be affected by P-gp expression, and has favorable pharmacokinetic properties (Table 6) [57, 142].

\section{Immunosuppressants}

Recipients of a HCT, particularly allogeneic HCT, require immunosuppression to prevent GVHD [149]. Tacrolimus, sirolimus, or cyclosporine are often utilized for GVHD prophylaxis (Table 7). Similar to the approach in solid organ transplant patients, these medications are managed within a narrow therapeutic window in attempt to decrease both the risk of GVHD as well as toxicities of therapy. Additionally, practitioners should remain cognizant of DDIs with these agents [1].

Corticosteroids are universally utilized immunosuppressants in oncology patients. Often times, corticosteroids are included in different chemotherapy regimens, especially to treat diseases such as diffuse large b-cell lymphoma or acute lymphoid leukemia. High-dose corticosteroids are also utilized to treat a wide range of complications in cancer patients, including but not limited to GVHD, diffuse alveolar hemorrhage (DAH), idiopathic pulmonary syndrome (IPS), and spinal cord compression (SCC) (Table 7). Collaboration between the oncology and critical care teams is recommended when initiating or stopping corticosteroids in the ICU to avoid untoward interactions with ongoing oncologic treatments.

\section{Antifibrinolytic/Antihemophilic Agents}

\section{Diffuse Alveolar Hemorrhage (DAH)}

Prognosis in patients with DAH secondary to cancer therapy or sepsis is poor [39]. Pulse dose corticosteroids (methylprednisolone 1-2 $\mathrm{mg} / \mathrm{kg}$ / day) with or without antifibrinolytic therapy has been used in practice but has not been consistently associated with reductions in ICU or hospital mortality, ventilator days, or ICU and hospital length of stay in the literature $[77,113,143]$. Treatment with steroids or antifibrinolytic therapy can be considered in patients at high risk of rapid 


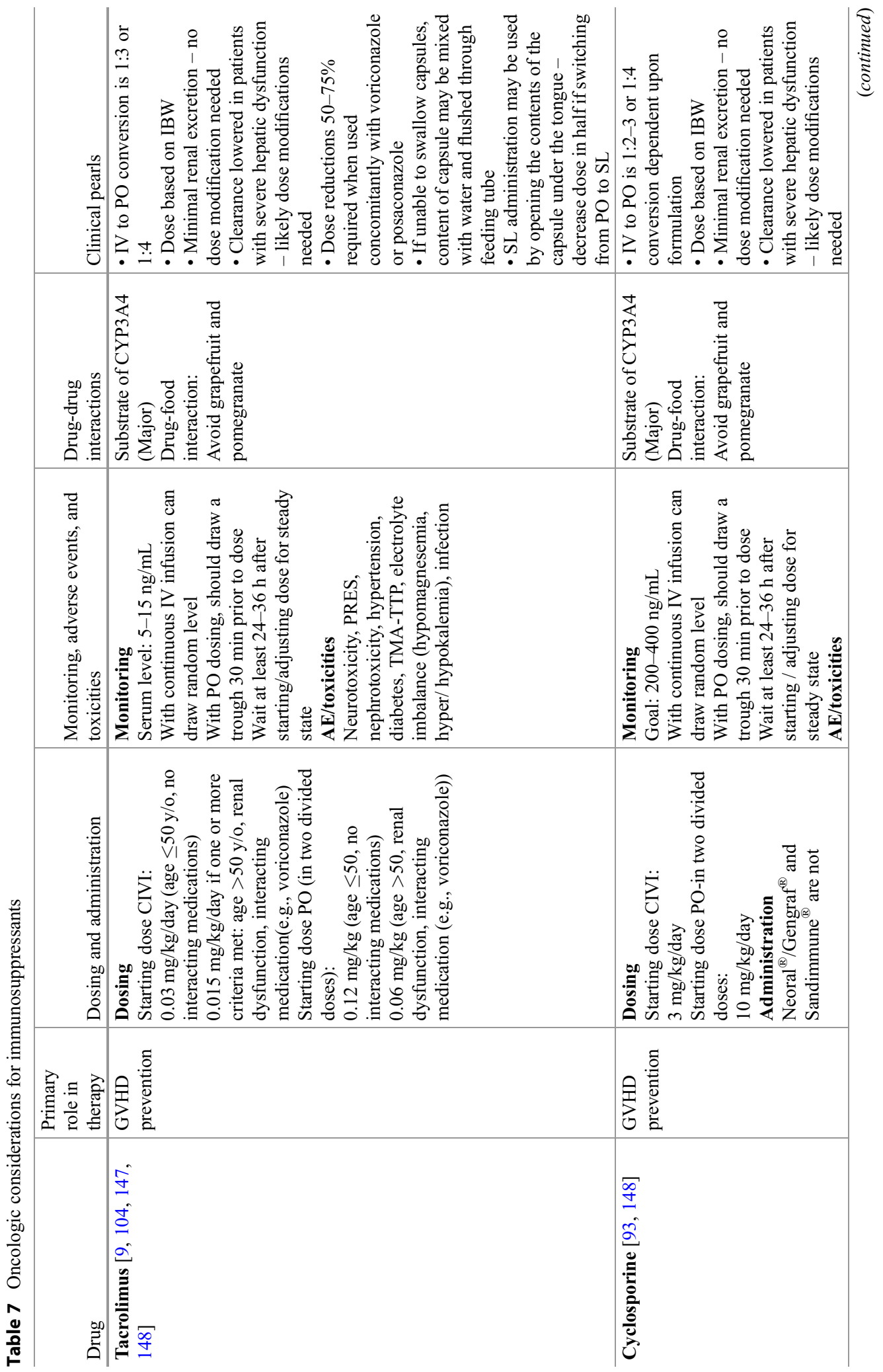




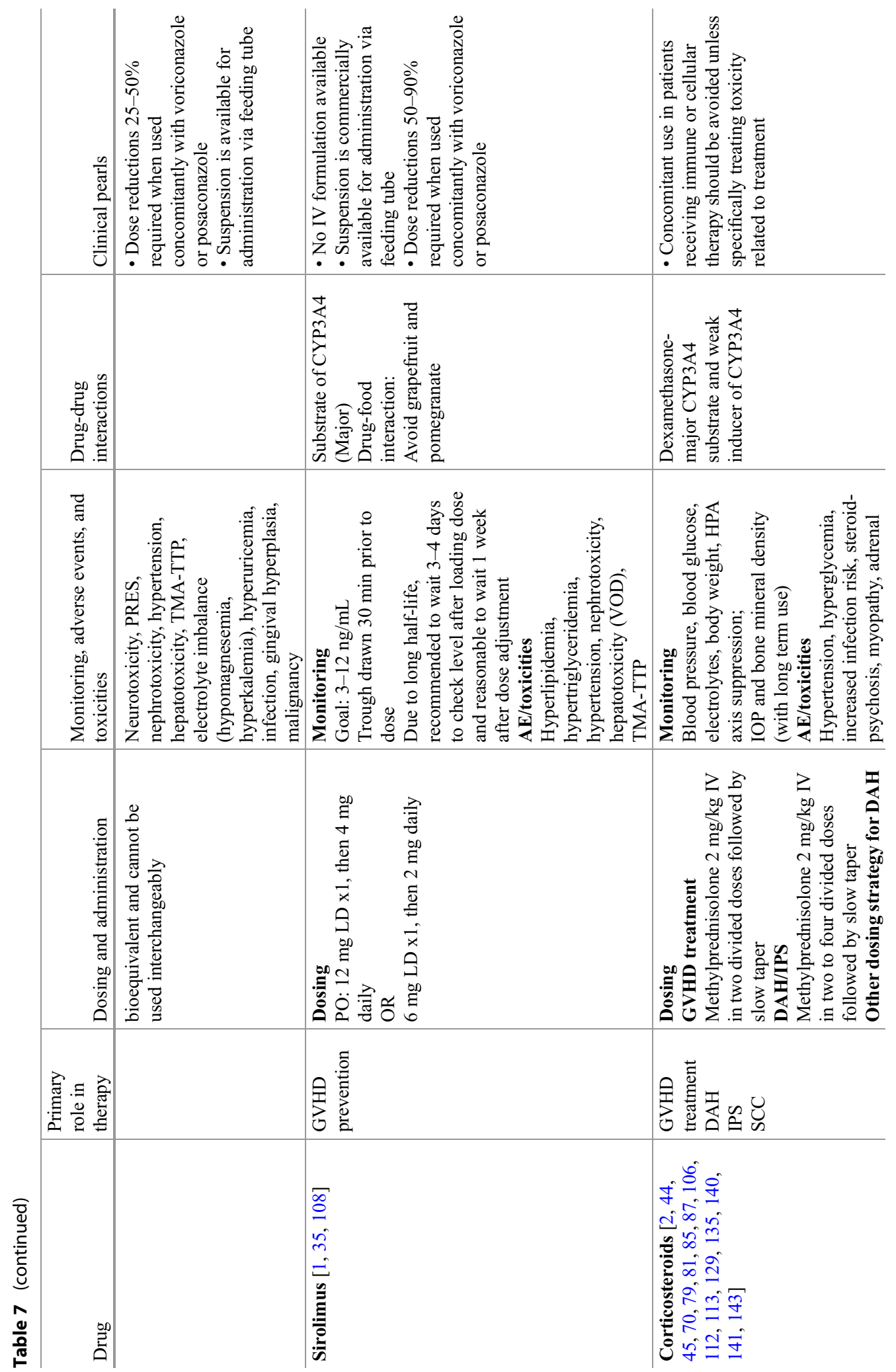




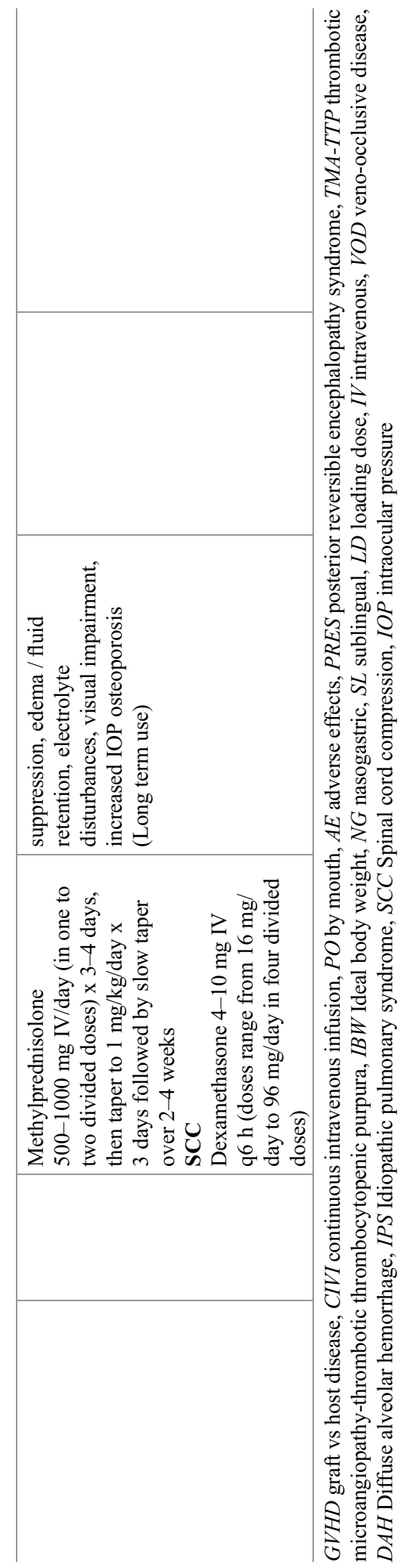


clinical deterioration or death (Table 8). Agents such as recombinant factor VIIa have been used to achieve hemostasis in non-hemophiliac patients with DAH [100]. Additionally, a case series of six patients successfully used intrapulmonary factor VII as adjunctive treatment for DAH with doses ranging from 30 to $60 \mathrm{mcg} / \mathrm{kg}$ [12]. The potential benefit of antifibrinolytic and antihemophilic therapies must be weighed against the risk of thrombotic events [150].

\section{Thrombocytopenia}

Spontaneous bleeding complications due to thrombocytopenia are common in the critically ill oncologic patient population [75]. Most patients can be managed by observation and supportive care alone. Use of antifibrinolytic agents have been used in emergency treatment of severe thrombocytopenia-associated bleeding to reduce transfusion requirements without increased risk in thromboembolic events (Table 8) but have not been shown to decrease mortality [7].

\section{Disseminated Intravascular Coagulation (DIC)}

Routine use of aminocaproic acid, tranexamic acid and recombinant FVIIa in patients with cancer-related DIC is not recommended. Practitioners may consider use of tranexamic acid in patients with therapy-resistant hyperfibrinolytic DIC bleeding (Table 8). Platelet transfusion to maintain platelets $>50 \times 10^{3} / \mathrm{L}$, and transfusion of fresh frozen plasma $(15-30 \mathrm{ml} / \mathrm{kg})$ with careful monitoring, is the primary therapy in patients with DIC and active bleeding [134].

\section{Gastrointestinal (GI) Bleeding}

A large randomized control trial (RCT) is currently underway to examine the use of tranexamic acid for the treatment of GI bleeding [118].

\section{Thrombolytics}

Hepatic sinusoidal obstruction syndrome (SOS), previously referred to as veno-occlusive disease (VOD), is a potentially life-threatening complication with a wide-ranging incidence. Severe SOS is associated with a mortality rate greater than $80 \%$ [27]. SOS is characterized by a prothrombotic, hypofibrinolytic state as a result of endothelial damage and hepatocellular injury to sinusoidal endothelial cells. Hallmark symptoms include weight gain, painful hepatomegaly, fluid retention/ascites, and hyperbilirubinemia; the reported incidence varies in part due to variable definitions and evaluated populations [36]. SOS is a complication that occurs typically within 3 weeks of a myeloablative HCT but can also be observed in patients with risk factors of pre-existing liver disease, total body irradiation or abdominal/liver radiation, or exposure to certain hepatotoxic drugs, such as inotuzumab or gemtuzumab (list of VOD/SOS risk factors is not all-inclusive) [27, 36]. Defibrotide was FDA approved in the United States in 2016 for the treatment of severe hepatic SOS after publication of a pivotal phase III trial [117]. Its proposed mechanism of action is to reduce endothelial cell activation and injury and promote restoration of the thrombo-fibrinolytic balance [116]. Due to the severity of illness associated with SOS, many patients are transferred to the ICU for continued management and administration of defibrotide (Table 9). 


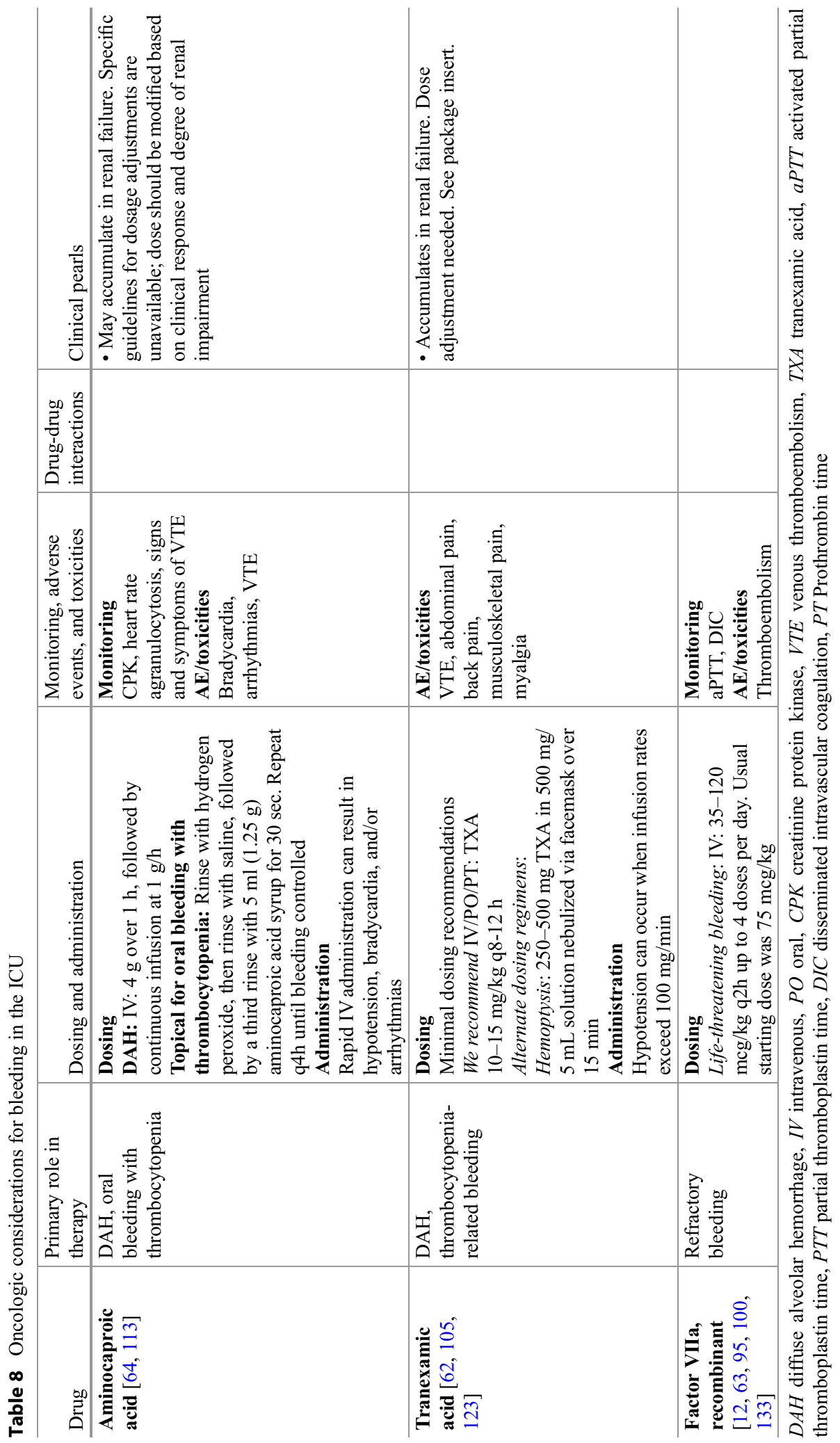


Table 9 Oncologic considerations for thrombolytics

\begin{tabular}{|c|c|c|c|c|c|}
\hline Drug & $\begin{array}{l}\text { Primary } \\
\text { role in } \\
\text { therapy }\end{array}$ & $\begin{array}{l}\text { Dosing and } \\
\text { administration }\end{array}$ & $\begin{array}{l}\text { Monitoring, } \\
\text { adverse events, } \\
\text { and toxicities }\end{array}$ & $\begin{array}{l}\text { Drug-drug } \\
\text { interactions }\end{array}$ & Clinical pearls \\
\hline $\begin{array}{l}\text { Defibrotide } \\
{[69,117]}\end{array}$ & $\begin{array}{l}\text { Hepatic } \\
\text { SOS } \\
\text { (VOD) }\end{array}$ & $\begin{array}{l}\text { Dosing } \\
\text { IV: } 6.25 \mathrm{mg} / \mathrm{kg} \text { q6h } \\
\text { for at least } 21 \text { days } \\
\text { and a maximum of } \\
60 \text { days (until SOS } \\
\text { resolution or hospital } \\
\text { discharge) } \\
\text { Utilize baseline (dry) } \\
\text { weight prior to stem } \\
\text { cell transplant or } \\
\text { initiation of } \\
\text { chemotherapy } \\
\text { Administration } \\
\text { Administer over } 2 \mathrm{~h} \\
\text { using } 0.2 \text { micron } \\
\text { in-line filter via a } \\
\text { dedicated line }\end{array}$ & $\begin{array}{l}\text { Monitoring } \\
\text { Platelets, INR, } \\
\text { Fibrinogen } \\
\text { AE/Toxicities } \\
\text { Hemorrhage, } \\
\text { Hypersensitivity } \\
\text { reaction } \\
\text { CI } \\
\text { Active bleeding, } \\
\text { hemodynamic } \\
\text { instability } \\
\text { requiring } \\
\text { vasopressor } \\
\text { support }\end{array}$ & $\begin{array}{l}\text { Co- } \\
\text { administration } \\
\text { with systemic } \\
\text { anticoagulation } \\
\text { or fibrinolytic } \\
\text { therapy is } \\
\text { contraindicated }\end{array}$ & $\begin{array}{l}\text { - For invasive } \\
\text { procedures - } \\
\text { discontinue defibrotide } \\
\text { at least } 2 \mathrm{~h} \text { prior to } \\
\text { procedure; resume } \\
\text { treatment once the } \\
\text { procedure-related risk } \\
\text { of bleeding is resolved } \\
\text { - Maintain platelets } \\
>30,000, \text { INR }<1.5 \text {, } \\
\text { Fibrinogen }>150 \text { to } \\
\text { decrease bleeding risk }\end{array}$ \\
\hline
\end{tabular}

SOS Sinusoidal obstruction syndrome, $V O D$ Veno-occlusive disease, $I V$ intravenous, INR International normalized ratio, $A E$ : adverse effects, $C I$ Contraindications

\section{Uric Acid Reducing Agents}

Over $50 \%$ of oncologic patients with high-risk for tumor lysis syndrome (TLS) require ICU admission, and nearly $1 / 3$ of those will present with acute kidney injury (AKI). Clinicians should be familiar with the management of hyperuricemia to help preserve renal function. Hyperuricemia results from the rapid release and catabolism of intracellular nucleic acids either spontaneously or in response to chemotherapy in patients with a high tumor burden. Patients who are considered high risk for TLS should receive rasburicase over allopurinol (Table 10) [25].

\section{Hypercalcemia of Malignancy/ Hypercalcemia Management}

All patients presenting with hypercalcemia of malignancy should be given IV crystalloids at $1-2 \mathrm{ml} / \mathrm{kg} / \mathrm{h}$ to restore intravascular volume and promote calciuresis. For patients that are fluid restricted due to other co-morbidities (e.g., heart failure), consider concomitant diuresis with a loop diuretic if necessary. Symptomatic patients presenting with abdominal pain, confusion, weakness, and electrocardiogram (EKG) changes may require a bisphosphonate $+/-$ calcitonin. Critical care practitioners should be cognizant of all prior therapy given in order to avoid duplicating therapy and the potential development of hypocalcemia (e.g., recent bisphosphonate or denosumab administration) (Table 11).

\section{Interleukin-6 Receptor Antagonists}

Chimeric antigen receptor (CAR) T-cell therapy induces rapid and durable clinical responses in many types of cancer but is associated with unique, acute toxicities that can be fatal. This includes both cytokine release syndrome (CRS) and cytokine-related encephalopathy syndrome (CRES). IL-6 therapy may be warranted in patients exhibiting signs and symptoms of toxicity, particularly those requiring ICU care. IL-6 receptor antagonists are indicated in patients with grade 2 and greater CRES and grade 3 and $4 \mathrm{CRS}$, and may be considered in those with grade 1 CRES and/or persistent grade 1 or 2 CRS [91]. See Table 12 for considerations for IL-6 therapy for CRS or CRES. 


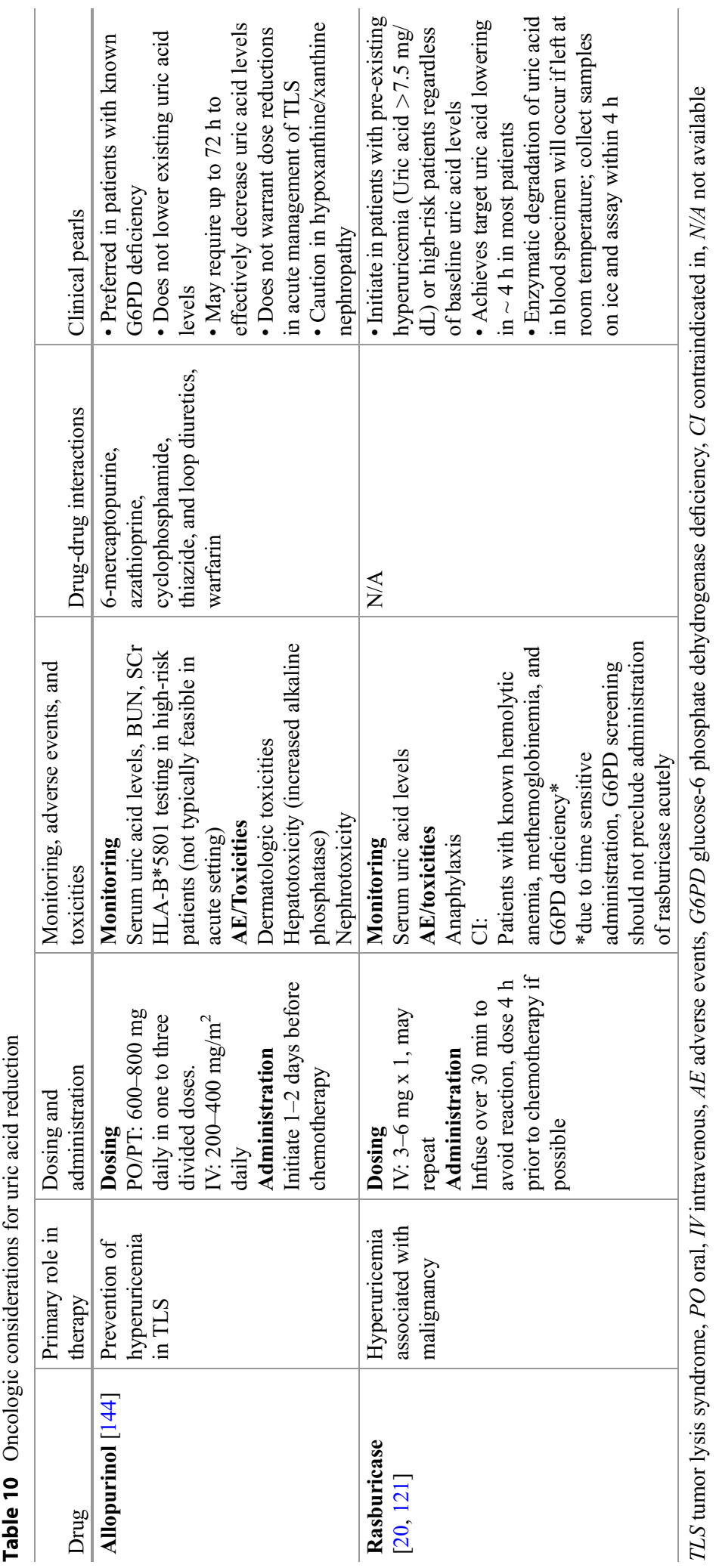




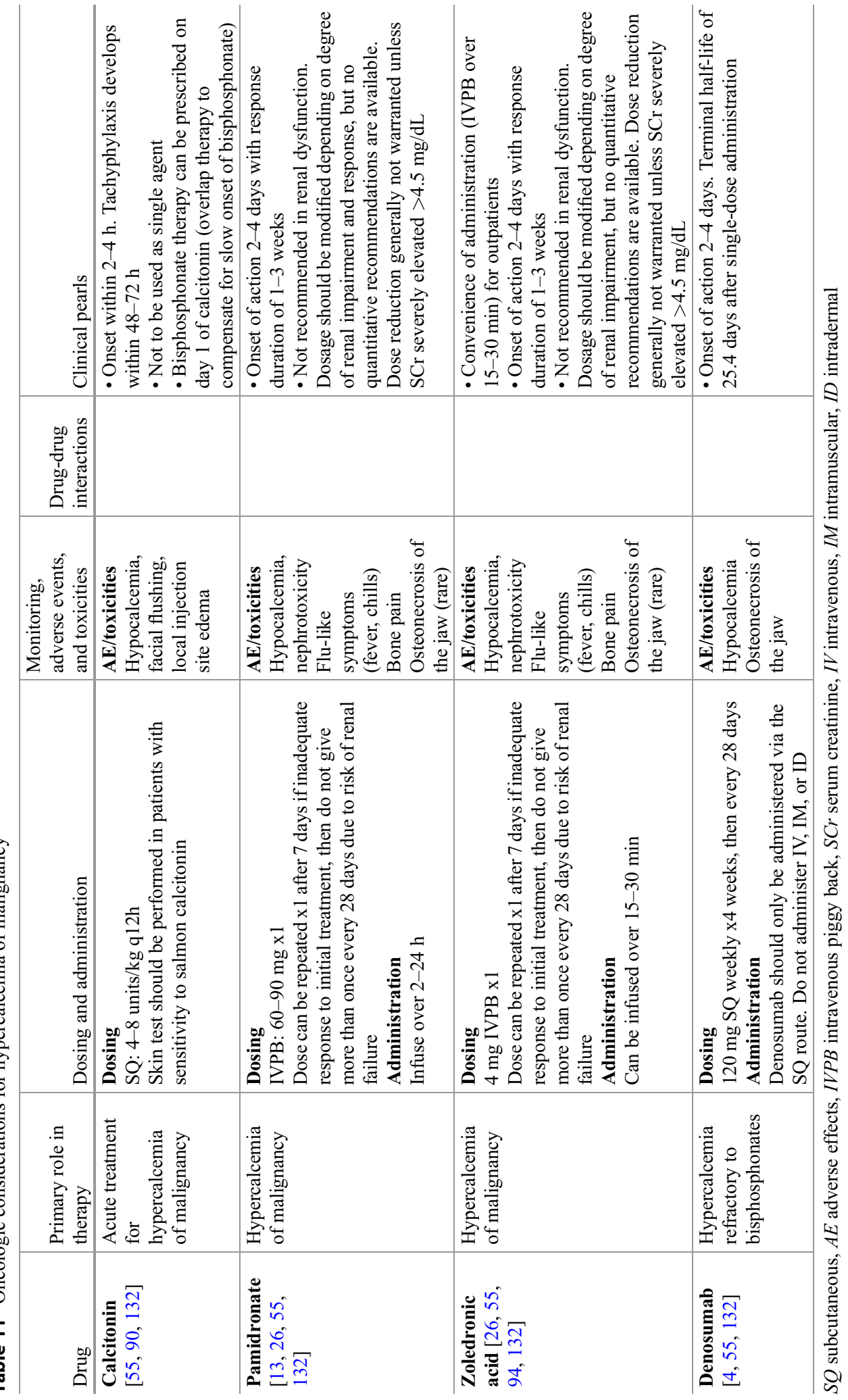


Table 12 Oncologic considerations for treatment of cytokine release syndrome or cytokine related encephalopathy syndrome

\begin{tabular}{|c|c|c|c|c|c|}
\hline Drug & $\begin{array}{l}\text { Primary } \\
\text { role in } \\
\text { therapy }\end{array}$ & $\begin{array}{l}\text { Dosing and } \\
\text { administration }\end{array}$ & $\begin{array}{l}\text { Monitoring, adverse } \\
\text { events, and toxicities }\end{array}$ & $\begin{array}{l}\text { Drug-drug } \\
\text { interactions }\end{array}$ & Clinical pearls \\
\hline Tocilizumab [48] & $\begin{array}{l}\text { CRS } \\
\text { CRES }\end{array}$ & $\begin{array}{l}\text { Dosing } \\
\text { IV: } 8 \mathrm{mg} / \mathrm{kg} \text { for } \\
\text { up to } 3 \text { doses in a } \\
24-\mathrm{h} \text { period (max } \\
800 \mathrm{mg} / \text { dose) } \\
\text { Administration } \\
\text { Infuse over } 1 \mathrm{~h} \\
\text { No } \\
\text { premedications } \\
\text { needed } \\
\text { Have emergency } \\
\text { medications } \\
\text { immediately } \\
\text { available in the } \\
\text { event of } \\
\text { hypersensitivity } \\
\text { reaction }\end{array}$ & $\begin{array}{l}\text { Monitoring prior to } \\
\text { therapy } \\
\text { Latent TB,CBC with } \\
\text { diff, LFTs, lipid panel } \\
\text { AE/Toxicities } \\
\text { Infection, infusion } \\
\text { reaction, anaphylaxis, } \\
\text { GI perforation, CNS } \\
\text { demyelinating } \\
\text { disorders, increased } \\
\text { cholesterol, increased } \\
\text { LFTs, infusion } \\
\text { reactions, neutropenia, } \\
\text { thrombocytopenia }\end{array}$ & $\begin{array}{l}\text { Theoretical } \\
\text { increased } \\
\text { metabolism of } \\
\text { CYP } \\
450 \text { substrates }\end{array}$ & $\begin{array}{l}\text { - May consider } \\
\text { re-dosing in } \\
\text { patients not } \\
\text { responding or with } \\
\text { worsening grade } \\
\text { toxicities within } \\
4 \mathrm{~h} \text {. }\end{array}$ \\
\hline Siltuximab [68] & $\begin{array}{l}\text { CRS } \\
\text { CRES }\end{array}$ & $\begin{array}{l}\text { Dosing } \\
\text { IV: } 11 \mathrm{mg} / \mathrm{kg} \\
\text { once } \\
\text { Administration } \\
\text { Infuse over } 1 \mathrm{~h} \text {; } \\
\text { complete } \\
\text { infusion within } \\
4 \mathrm{~h} \text { of } \\
\text { reconstitution } \\
\text { No } \\
\text { premedications } \\
\text { needed } \\
\text { Have emergency } \\
\text { medications } \\
\text { immediately } \\
\text { available in the } \\
\text { event of } \\
\text { hypersensitivity } \\
\text { reaction }\end{array}$ & $\begin{array}{l}\text { Monitoring prior to } \\
\text { therapy } \\
\text { CBC prior to first dose } \\
\text { AE/Toxicities } \\
\text { Infection, infusion } \\
\text { reaction, anaphylaxis, } \\
\text { GI perforation, } \\
\text { peripheral edema, } \\
\text { fatigue (long-term } \\
\text { exposure), pruritus, } \\
\text { skin rash, weight gain, } \\
\text { hyperuricemia, } \\
\text { diarrhea, abdominal } \\
\text { pain, arthralgia, URI, } \\
\text { thrombocytopenia, } \\
\text { hypertriglyceridemia }\end{array}$ & $\begin{array}{l}\text { Theoretical } \\
\text { increased } \\
\text { metabolism of } \\
\text { CYP } \\
450 \text { substrates }\end{array}$ & $\begin{array}{l}\text { - Do not re-dose } \\
\text { within } 21 \text { days } \\
\text { - Consider in } \\
\text { patients who fail to } \\
\text { respond to } 1-2 \\
\text { doses of } \\
\text { tocilizumab }\end{array}$ \\
\hline
\end{tabular}

$C R S$ cytokine release syndrome, $C R E S$ cytokine related encephalopathy syndrome, $I V$ intravenous, $T B$ tuberculosis, $C B C$ complete blood count, diff differential, $L F T s$ liver function tests, $A E$ adverse effects, $G I$ gastrointestinal, $C N S$ cerebral nervous system, $C B C$ : complete blood count, $U R I$ upper respiratory infection

\section{Growth Factors}

Colony stimulating factors (CSF) are recommended to be administered in a prophylactic manner when the risk of febrile neutropenia (FN) with a given chemotherapy regimen is $20 \%$ or higher [127]. The American Society of Clinical Oncology (ASCO) and National Comprehensive
Cancer Network (NCCN) recommend primary prophylaxis for FN with CSFs based on factors associated with the disease, chemotherapy regimen, patient risk, and treatment intent (curative vs. palliative). Secondary prophylaxis may be warranted in patients who have FN or a doselimiting neutropenic event [31, 127]. Additionally, CSFs may be used to reduce the length of hospitalization and time to neutrophil recovery, for 
Table 13 Oncologic considerations for growth factors in the ICU

\begin{tabular}{|c|c|c|c|c|c|}
\hline Drug & $\begin{array}{l}\text { Primary } \\
\text { role in } \\
\text { therapy }\end{array}$ & $\begin{array}{l}\text { Dosing and } \\
\text { administration }\end{array}$ & $\begin{array}{l}\text { Monitoring, adverse } \\
\text { events, and toxicities }\end{array}$ & $\begin{array}{l}\text { Drug-drug } \\
\text { interactions }\end{array}$ & Clinical pearls \\
\hline Filgrastim [6] & $\begin{array}{l}\text { Increase } \\
\text { WBC }\end{array}$ & $\begin{array}{l}\text { Dosing } \\
5 \mathrm{mcg} / \mathrm{kg} / \text { day IV/SQ }\end{array}$ & $\begin{array}{l}\text { Monitoring } \\
\text { CBC with differential } \\
\text { AE/toxicities } \\
\text { Common: fatigue, } \\
\text { bone/joint pain, } \\
\text { peripheral edema/ } \\
\text { capillary leak } \\
\text { syndrome, } \\
\text { thrombocytopenia, } \\
\text { headache, } \\
\text { splenomegaly } \\
\text { Serious: ARDS, } \\
\text { pulmonary infiltrates, } \\
\text { splenic rupture }\end{array}$ & N/A & $\begin{array}{l}\text { - Higher doses } \\
\text { may be used } \\
\text { during } \\
\text { mobilization for } \\
\text { HCT } \\
\text { - Onset of action, } \\
24 \text { h } \\
\text { - Duration: Counts } \\
\text { return to baseline } \\
\text { within } 4 \text { days } \\
\text { - Do not } \\
\text { administer within } \\
24 \text { h (before or } \\
\text { after) of cytotoxic } \\
\text { chemotherapy }\end{array}$ \\
\hline Pegfilgrastim [5] & $\begin{array}{l}\text { Increase } \\
\text { WBC }\end{array}$ & $\begin{array}{l}\text { Dosing } \\
6 \text { mg SQ once per } \\
\text { chemotherapy cycle, } \\
\text { beginning at least } \\
24 \text { h after completion } \\
\text { of chemotherapy }\end{array}$ & $\begin{array}{l}\text { Monitoring } \\
\text { CBC with differential } \\
\text { AE/toxicities } \\
\text { Common: bone/joint/ } \\
\text { muscle pain } \\
\text { Serious: ARDS, } \\
\text { pulmonary infiltrates, } \\
\text { splenic rupture }\end{array}$ & N/A & $\begin{array}{l}\text { - Onset of action is } \\
96 \text { h(delayed } \\
\text { compared to } \\
\text { filgrastim) } \\
\text { - Pegylated } \\
\text { formulation allows } \\
\text { for prolonged } \\
\text { duration of action } \\
\text { (half-life } 15-80 \mathrm{~h} \text { ) } \\
\text { - Do not } \\
\text { administer within } \\
14 \text { days before or } \\
24 \text { h after } \\
\text { cytotoxic } \\
\text { chemotherapy }\end{array}$ \\
\hline Romiplostim [3] & $\begin{array}{l}\text { Increase } \\
\text { platelets } \\
\text { in } \\
\text { chronic } \\
\text { ITP }\end{array}$ & $\begin{array}{l}\text { Dosing } \\
1 \mathrm{mcg} / \mathrm{kg} \text { SQ once } \\
\text { weekly; increasing } \\
\text { by } 1 \mathrm{mcg} / \mathrm{kg} / \text { week } \\
\text { increments to achieve } \\
\text { platelet count } \\
\geq 50,000 / \mathrm{mm}^{3}(\mathrm{Max} \\
\text { dose: } 10 \mathrm{mcg} / \mathrm{kg} / \\
\text { week) }\end{array}$ & $\begin{array}{l}\text { Monitoring } \\
\text { CBC with differential } \\
\text { AE/toxicities } \\
\text { Common: headache, } \\
\text { dizziness, abdominal } \\
\text { pain, arthralgia, } \\
\text { myalgia, increased } \\
\text { circulating } \\
\text { myeloblasts (MDA } \\
\text { patients) } \\
\text { Serious: angioedema, } \\
\text { marrow fibrosis, } \\
\text { VTE, hematology } \\
\text { malignancy risk }\end{array}$ & & $\begin{array}{l}\text { - Onset of action } \\
\text { between 4-9 days } \\
\text { - Should be } \\
\text { discontinued after } \\
4 \text { weeks if no } \\
\text { response } \\
\text { - Upon } \\
\text { discontinuation of } \\
\text { therapy, may see } \\
\text { rebound } \\
\text { thrombocytopenia } \\
\text { and increased } \\
\text { bleeding risk } \\
\text { - May be used off } \\
\text { label to increase } \\
\text { platelet count if } \\
\text { high risk for } \\
\text { bleeding or for } \\
\text { CIT }\end{array}$ \\
\hline
\end{tabular}

$W B C$ white blood cell, $I V$ intravenous, $S Q$ subcutaneous, $C B C$ complete blood count, $A E$ adverse effects, $A R D S$ acute respiratory distress syndrome, ITP idiopathic thrombocytopenia purpura, VTE venous thromboembolism, CIT chemotherapy-induced thrombocytopenia 
Table 14 Antidotes for critically Ill oncologic patients

\begin{tabular}{|c|c|c|c|c|c|}
\hline Drug & $\begin{array}{l}\text { Primary role in } \\
\text { therapy }\end{array}$ & $\begin{array}{l}\text { Dosing and } \\
\text { administration }\end{array}$ & $\begin{array}{l}\text { Monitoring, } \\
\text { adverse events, } \\
\text { and toxicities }\end{array}$ & $\begin{array}{l}\text { Drug-drug } \\
\text { interactions }\end{array}$ & Clinical pearls \\
\hline $\begin{array}{l}\text { Sodium } \\
\text { bicarbonate } \\
\text { or sodium } \\
\text { acetate }[65]\end{array}$ & $\begin{array}{l}\text { Urinary } \\
\text { alkalinization } \\
\text { for } \\
\text { methotrexate } \\
\text { toxicity }\end{array}$ & $\begin{array}{l}\text { Dosing } \\
\text { Dose: IV: } 50 \text { meq/ } \\
\text { L to maximally } \\
\text { tolerated rate } \\
\left(\geq 3 \mathrm{~L} / \mathrm{m}^{2} \text { per day) }\right. \\
\text { to maximize urine } \\
\text { output and keep } \\
\text { urine } \mathrm{pH}>7\end{array}$ & $\begin{array}{l}\text { AE/Toxicities } \\
\text { Metabolic } \\
\text { alkalosis }\end{array}$ & & $\begin{array}{l}\text { - Limited } \\
\text { compatibility with } \\
\text { many other IV } \\
\text { medications }\end{array}$ \\
\hline Amifostine [122] & $\begin{array}{l}\text { Cisplatin } \\
\text { toxicity }\end{array}$ & $\begin{array}{l}\text { Dosing } \\
\text { Dose: IV: } 910 \mathrm{mg} / \\
\mathrm{m}^{2} \text { over } 15 \mathrm{~min} \\
\text { once daily given } \\
30 \text { min prior to } \\
\text { chemotherapy. } \\
\text { Chemotherapy } \\
\text { should be started } \\
15 \text { min after } \\
\text { completion of } \\
\text { amifostine } \\
\text { infusion. }\end{array}$ & $\begin{array}{l}\text { Monitoring } \\
\text { BP every 3-5 min } \\
\text { during infusion } \\
\text { and decrease dose } \\
\text { for severe } \\
\text { decrease in SBP } \\
\text { (see dosage } \\
\text { adjustments from } \\
\text { package insert). If } \\
\text { full dose cannot be } \\
\text { administered prior } \\
\text { to cisplatin } \\
\text { therapy, reduce } \\
\text { amifostine dose to } \\
740 \text { mg/m }{ }^{2} \text { for } \\
\text { subsequent cycles } \\
\text { AE/Toxicities } \\
\text { Hypotension, N/V }\end{array}$ & $\begin{array}{l}\text { Patients should } \\
\text { have } \\
\text { antihypertensive } \\
\text { therapy } \\
\text { interrupted } 24 \mathrm{~h} \\
\text { before receiving } \\
\text { amifostine }\end{array}$ & $\begin{array}{l}\text { - Cytoprotective } \\
\text { detoxicant. } \\
\text { Reduces } \\
\text { ototoxicity, } \\
\text { nephrotoxicity, } \\
\text { and possible } \\
\text { decrease in } \\
\text { severity of } \\
\text { peripheral } \\
\text { neuropathy } \\
\text { - Premedicate with } \\
\text { antiemetics } \\
\text { including } \\
\text { dexamethasone } \\
\text { and a serotonin } \\
\text { 5HT }{ }_{3} \text { receptor } \\
\text { antagonist }\end{array}$ \\
\hline Dexrazoxane [107] & $\begin{array}{l}\text { Extravasation } \\
\text { Doxorubicin } \\
\text { toxicity }\end{array}$ & $\begin{array}{l}\text { Dosing } \\
\text { First infusion } \\
\text { should be started } \\
\text { within } 6 \mathrm{~h} \text { after } \\
\text { extravasation } \\
\text { IV: } \\
\text { Day } 1: 1,000 \mathrm{mg} / \\
\mathrm{m} 2 \text { (max } \\
2000 \mathrm{mg} / \mathrm{day}) \\
\text { Day } 2: 1,000 \mathrm{mg} / \\
\mathrm{m} 2(\mathrm{Max}: \\
2000 \mathrm{mg}) \\
\text { Day } 3: 500 \mathrm{mg} / \mathrm{m} 2 \\
\text { (Max } 1000 \mathrm{mg}) \\
\text { Infusions on day } \\
2 \text { and } 3 \mathrm{should} \\
\text { start at the same } \\
\text { hour }( \pm 3 \mathrm{~h}) \text { as on } \\
\text { the first day }\end{array}$ & $\begin{array}{l}\text { AE/Toxicities } \\
\text { myelosuppression }\end{array}$ & & $\begin{array}{l}\text { - Remove cooling } \\
\text { procedures (e.g., } \\
\text { ice packs) from } \\
\text { area at least } \\
15 \text { min prior to } \\
\text { administration to } \\
\text { allow sufficient } \\
\text { blood flow to area }\end{array}$ \\
\hline Leucovorin [65] & $\begin{array}{l}\text { Primary therapy } \\
\text { for MTX } \\
\text { toxicity }\end{array}$ & $\begin{array}{l}\text { Dosing } \\
\text { IV, IM, or PO: } \\
\text { Initially } 15 \mathrm{mg} \\
\left(10 \mathrm{mg} / \mathrm{m}^{2}\right), \text { then } \\
15 \mathrm{mg}\left(10 \mathrm{mg} / \mathrm{m}^{2}\right) \\
\text { q6h until serum } \\
\text { MTX }<0.05 \\
\text { uM/L. } \\
\text { Subsequent }\end{array}$ & $\begin{array}{l}\text { AE/Toxicities } \\
\text { Dehydration, } \\
\text { diarrhea }\end{array}$ & & $\begin{array}{l}\text { - Do not } \\
\text { administer within } \\
2 \mathrm{~h} \text { before or after } \\
\text { glucarpidase } \\
\text { - Do not exceed } \\
\text { infusion rate of } \\
160 \mathrm{mg} \text { of } \\
\text { leucovorin per } \\
\text { minute due to }\end{array}$ \\
\hline
\end{tabular}


Table 14 (continued)

\begin{tabular}{|c|c|c|c|c|c|}
\hline Drug & $\begin{array}{l}\text { Primary role in } \\
\text { therapy }\end{array}$ & $\begin{array}{l}\text { Dosing and } \\
\text { administration }\end{array}$ & $\begin{array}{l}\text { Monitoring, } \\
\text { adverse events, } \\
\text { and toxicities }\end{array}$ & $\begin{array}{l}\text { Drug-drug } \\
\text { interactions }\end{array}$ & Clinical pearls \\
\hline & & $\begin{array}{l}\text { dosing based on } \\
\text { follow-up MTX } \\
\text { levels [65] } \\
\text { If } \mathrm{SCr} \geq 50 \% \\
\text { baseline } 24 \mathrm{~h} \text { post } \\
\text { MTX, or if serum } \\
\text { MTX }>5 \mathrm{uM} / \mathrm{L} \text {, } \\
\text { increase } \\
\text { leucovorin to } \\
100 \mathrm{mg} / \mathrm{m}^{2} \mathrm{IV} \text { or } \\
\text { q3h until serum } \\
\text { MTX }<0.05 \\
\mathrm{uM} / \mathrm{L} .\end{array}$ & & & $\begin{array}{l}\text { calcium content of } \\
\text { solution }\end{array}$ \\
\hline Glucarpidase [65] & $\begin{array}{l}\text { MTX toxicity in } \\
\text { patients with } \\
\text { renal } \\
\text { dysfunction }\end{array}$ & $\begin{array}{l}\text { Dosing } \\
\text { IV: } 50 \mathrm{U} / \mathrm{g} \text { over } \\
5 \mathrm{~min}\end{array}$ & $\begin{array}{l}\text { Monitoring } \\
\text { Serum MTX } \\
\text { reduced by } \geq 97 \% \\
\text { within } 15 \text { min of } \\
\text { dose } \\
\text { administration }\end{array}$ & & $\begin{array}{l}\text { - MTX TDM is } \\
\text { unreliable for at } \\
\text { least } 48 \mathrm{~h} \\
\text { following } \\
\text { glucarpidase } \\
\text { administration } \\
\text { - No effect on } \\
\text { intracellular MTX } \\
\text { concentrations. } \\
\text { Must be } \\
\text { administered with } \\
\text { high-dose } \\
\text { leucovorin }\end{array}$ \\
\hline Levocarnitine [15] & $\begin{array}{l}\text { Pegaspargase- } \\
\text { induced } \\
\text { hepatotoxicity }\end{array}$ & $\begin{array}{l}\text { Dosing } \\
\text { IV LD: } 50 \mathrm{mg} / \mathrm{kg} \text {, } \\
\text { followed by } \\
50 \mathrm{mg} / \mathrm{kg} / \text { day } \\
\text { divided in six } \\
\text { daily doses }\end{array}$ & $\begin{array}{l}\text { AE/Toxicities } \\
\text { Diarrhea, } \\
\text { hypertension }\end{array}$ & $\begin{array}{l}\text { Patients who are } \\
\text { on antidiabetic } \\
\text { agents may need } \\
\text { dose adjustments } \\
\text { for } \\
\text { hypoglycemia }\end{array}$ & $\begin{array}{l}\text { - Use with caution } \\
\text { in patients with } \\
\text { history of seizures }\end{array}$ \\
\hline $\begin{array}{l}\text { Methylene blue } \\
{[103,115]}\end{array}$ & $\begin{array}{l}\text { Ifosfamide- } \\
\text { induced } \\
\text { neurotoxicity }\end{array}$ & $\begin{array}{l}\text { Dosing } \\
\text { IV: } 50 \mathrm{mg} \text { infused } \\
\text { up to six times } \\
\text { daily }\end{array}$ & $\begin{array}{l}\text { AE/Toxicities } \\
\text { Contraindicated in } \\
\text { patients with } \\
\text { G6PD deficiency } \\
\text { Dysgeusia, hot } \\
\text { flashes }\end{array}$ & $\begin{array}{l}\text { Avoid } \\
\text { concomitant use } \\
\text { with SSRIs, } \\
\text { SNRIs, and } \\
\text { MAOI therapy } \\
\text { due to risk of } \\
\text { serotonin } \\
\text { syndrome }\end{array}$ & $\begin{array}{l}\text { - Urine } \\
\text { discoloration } \\
\text { (blue or green) can } \\
\text { occur due to } \\
\text { oxidation when } \\
\text { exposed to air }\end{array}$ \\
\hline $\begin{array}{l}\text { Thiamine }[46,61 \text {, } \\
73,131]\end{array}$ & $\begin{array}{l}\text { Ifosfamide } \\
\text { toxicity } \\
\text { Beriberi } \\
\text { Wernicke's } \\
\text { Encephalopathy }\end{array}$ & $\begin{array}{l}\text { Dosing } \\
\text { Limited data: } \\
\text { IV: Ifosfamide } \\
\text { toxicity: } 100 \mathrm{mg} \\
\text { q4h } \\
\text { Beriberi: }\end{array}$ & & & $\begin{array}{l}\text { - Consider } \\
\text { thiamine for } \\
\text { Wernicke in the } \\
\text { malnourished and } \\
\text { confused } \\
\text { oncologic patient }\end{array}$ \\
\hline
\end{tabular}


Table 14 (continued)

\begin{tabular}{|c|c|c|c|c|c|}
\hline Drug & $\begin{array}{l}\text { Primary role in } \\
\text { therapy }\end{array}$ & $\begin{array}{l}\text { Dosing and } \\
\text { administration }\end{array}$ & $\begin{array}{l}\text { Monitoring, } \\
\text { adverse events, } \\
\text { and toxicities }\end{array}$ & $\begin{array}{l}\text { Drug-drug } \\
\text { interactions }\end{array}$ & Clinical pearls \\
\hline & & $\begin{array}{l}\text { IV: } 100 \mathrm{mg} / \text { day x } 7 \\
\text { days, followed by } \\
10 \mathrm{mg} / \text { day orally } \\
\text { until complete } \\
\text { recovery } \\
\text { Wernicke's } \\
\text { Encephalopathy: } \\
\text { IV: } 200 \mathrm{mg} \text { TID x } \\
5-7 \text { days or until } \\
\text { no further } \\
\text { improvement in } \\
\text { symptoms }\end{array}$ & & & \\
\hline
\end{tabular}

$I V$ intravenous, $A E$ adverse effects, $B P$ blood pressure, $S B P$ systolic blood pressure, $N / V$ nausea and vomiting, $M T X$ methotrexate, $I M$ intramuscular, $P O$ by mouth, $q 3 h$ every three hours, $T D M$ therapeutic drug monitoring, $L D$ loading dose, $T I D$ three times daily

HCT mobilization, and to reduce the risk of infection in patients with intermittent/persistent neutropenia status post HCT. Of note, the medical record of oncology patients admitted to the ICU should be evaluated for prior CSF administration as such therapy my confound interpretation of leukocytosis (Table 13).

Thrombopoietin and thrombopoietin mimetics are FDA approved for the treatment of chronic immune thrombocytopenia; these agents may also be helpful off label to increase the platelet count in patients with thrombocytopenic disorders $[66,74,76]$. The management of thrombocytopenia in patients with increased bleeding risk (e.g., post-surgical), chemotherapy-induce thrombocytopenia, and/or promotion of platelet engraftment after HCT are some examples of off-label uses for thrombopoietin agents, such as romiplostim (Table 13) [83, 86, 96, 128].

\section{Antidotes}

The toxicity profiles of chemotherapy regimens are often severe and adversely affect patients' quality of life. Although most symptoms can be managed with supportive care (see Table 1 in chapter entitled " $>$ Complications and Toxicities Associated with Cancer Therapies"), there are times when treatment interruptions or reversal are necessary.

For reversal of toxicities or overdose, infusion of antidote should be started as soon as possible (Table 14).

\section{References}

1. Abouelnasr A, Roy J, Cohen S, Kiss T, Lachance S. Defining the role of sirolimus in the management of graft-versus-host disease: from prophylaxis to treatment. Biol Blood Marrow Transplant. 2013;19(1):12-21. https://doi.org/ 10.1016/j.bbmt.2012.06.020.

2. Afessa B, Tefferi A, Litzow MR, Peters SG. Outcome of diffuse alveolar hemorrhage in hematopoietic stem cell transplant recipients. Am J Respir Crit 
Care Med. 2002;166(10):1364-8. https://doi.org/ 10.1164/rccm.200208-792OC.

3. Amgen Inc. Nplate (romiplostim) [package insert]. Thousand Oaks; 2008.

4. Amgen Inc. Xgeva (denosumab) [package insert]. Thousand Oaks; 2013.

5. Amgen Inc. Neulasta (pegfilgrastim) [package insert]. Thousand Oaks; 2015a.

6. Amgen Inc. Neupogen (filgrastim) [package insert]. Thousand Oaks; 2015b.

7. Antun AG, Gleason S, Arellano M, Langston AA, McLemore ML, Gaddh $\mathrm{M}$, el Rassi $\mathrm{F}$, Bernal-Mizrachi L, Galipeau J, Heffner LT Jr, Winton EF, Khoury HJ. Epsilon aminocaproic acid prevents bleeding in severely thrombocytopenic patients with hematological malignancies. Cancer. 2013;119(21):3784-7. https://doi.org/10.1002/ cncr. 28253.

8. Ashbee HR, Barnes RA, Johnson EM, Richardson MD, Gorton R, Hope WW. Therapeutic drug monitoring (TDM) of antifungal agents: guidelines from the British Society for Medical Mycology. J Antimicrob Chemother. 2014;69(5):1162-76. https://doi.org/10.1093/jac/dkt508.

9. Astellas Pharma. Prograf (tacrolimus) [package insert]. Deerfield; 2012.

10. Astellas Pharma. Cresemba (Isavuconazonium sulfate) [package insert]. Northbrook; 2015.

11. Baden LR, Swaminathan S, Almyroudis NG, Angarone M, Blouin G, Camins BC, Cooper B, Dubberke ER, Engemann AM, Freifeld AG, Greene JN, Gregg K, Hakim H, Ito. IJ, Lustberg ME, Mones JV, Pergam S, Rolston K, Satyanarayana G, Schulz L, Seo SK, Shoham S, Taplitz R, Topal J, Wilson JW. Prevention and treatment of cancer-related infections, Version 1.2018. NCCN Clinical Practice Guidelines in Oncology; 2018.

12. Baker MS, Diab KJ, Carlos WG, Mathur P. Intrapulmonary recombinant factor VII as an effective treatment for diffuse alveolar hemorrhage: a case series. J Bronchol Intervent Pulmonol. 2016;23(3):255-8. https://doi.org/ 10.1097/lbr.0000000000000286.

13. Ben Venue Laboratories I. Aredia (pamidronate) [package insert]. Bedford; 2009.

14. Blackburn LM, Tverdek FP, Hernandez M, Bruno JJ. First-dose pharmacokinetics of aminoglycosides in critically ill haematological malignancy patients. Int $\mathrm{J}$ Antimicrob Agents. 2015;45(1):46-53. https://doi.org/10.1016/j. ijantimicag.2014.09.006.

15. Blackman A, Boutin A, Shimanovsky A, Baker WJ, Forcello N. Levocarnitine and vitamin B complex for the treatment of pegaspargase-induced hepatotoxicity: a case report and review of the literature. J Oncol Pharm Pract. 2017; https://doi.org/10.1177/ 1078155217710714.
16. Boeckh M, Ljungman P. How we treat cytomegalovirus in hematopoietic cell transplant recipients. Blood. 2009;113(23):5711-9. https://doi.org/ 10.1182/blood-2008-10-143560.

17. Brodie MJ, Mintzer S, Pack AM, Gidal BE, Vecht CJ, Schmidt D. Enzyme induction with antiepileptic drugs: cause for concern? Epilepsia. 2013;54(1):11-27. https://doi.org/10.1111/j.15281167.2012.03671.x.

18. Brody SR, Humphreys MH, Gambertoglio JG, Schoenfeld P, Cundy KC, Aweeka FT. Pharmacokinetics of cidofovir in renal insufficiency and in continuous ambulatory peritoneal dialysis or high-flux hemodialysis. Clin Pharmacol Ther. 1999;65(1):21-8. https://doi. org/10.1016/s0009-9236(99)70118-9.

19. Brophy GM, Bell R, Claassen J, Alldredge B, Bleck TP, Glauser T, Laroche SM, Riviello JJ Jr, Shutter L, Sperling MR, Treiman DM, Vespa PM. Guidelines for the evaluation and management of status epilepticus. Neurocrit Care. 2012;17(1):3-23. https://doi.org/10.1007/s12028012-9695-Z.

20. Cairo MS, Coiffier B, Reiter A, Younes A. Recommendations for the evaluation of risk and prophylaxis of tumour lysis syndrome (TLS) in adults and children with malignant diseases: an expert TLS panel consensus. Br J Haematol. 2010;149(4):578-86. https://doi.org/10.1111/j.13652141.2010.08143.x.

21. Casper C, Englund J, Boeckh M. How I treat influenza in patients with hematologic malignancies. Blood. 2010;115(7):1331-42. https://doi.org/ 10.1182/blood-2009-11-255455.

22. Chemaly RF, Aitken SL, Wolfe CR, Jain R, Boeckh MJ. Aerosolized ribavirin: the most expensive drug for pneumonia. Transpl Infect Dis. 2016;18(4):634-6. https://doi.org/10.1111/tid.12551.

23. Chemaly RF, Shah DP, Boeckh MJ. Management of respiratory viral infections in hematopoietic cell transplant recipients and patients with hematologic malignancies. Clin Infect Dis. 2014;59(Suppl 5): S344-51. https://doi.org/10.1093/cid/ciu623.

24. Cho SY, Lee DG, Choi SM, Park C, Chun HS, Park YJ, Choi JK, Lee HJ, Park SH, Choi JH, Yoo JH. Stenotrophomonas maltophilia bloodstream infection in patients with hematologic malignancies: a retrospective study and in vitro activities of antimicrobial combinations. BMC Infect Dis. 2015;15:69. https://doi.org/10.1186/s12879-015-0801-7.

25. Coiffier B, Altman A, Pui CH, Younes A, Cairo MS. Guidelines for the management of pediatric and adult tumor lysis syndrome: an evidencebased review. J Clin Oncol. 2008;26(16):2767-78. https://doi.org/10.1200/jco.2007.15.0177.

26. Coleman R, Body JJ, Aapro M, Hadji P, Herrstedt J. Bone health in cancer patients: ESMO Clinical Practice Guidelines. Ann Oncol. 
2014;25(Suppl 3):iii124-37. https://doi.org/10.1093/ annonc/mdu103.

27. Coppell JA, Richardson PG, Soiffer R, Martin PL, Kernan NA, Chen A, Guinan E, Vogelsang G, Krishnan A, Giralt S, Revta C, Carreau NA, Iacobelli $\mathrm{M}$, Carreras $\mathrm{E}$, Ruutu $\mathrm{T}$, Barbui $\mathrm{T}$, Antin JH, Niederwieser D. Hepatic veno-occlusive disease following stem cell transplantation: incidence, clinical course, and outcome. Biol Blood Marrow Transplant. 2010;16(2):157-68. https://doi. org/10.1016/j.bbmt.2009.08.024.

28. Cornely OA, Arikan-Akdagli S, Dannaoui E, Groll AH, Lagrou K, Chakrabarti A, Lanternier F, Pagano L, Skiada A, Akova M, Arendrup MC, Boekhout T, Chowdhary A, Cuenca-Estrella M, Freiberger T, Guinea J, Guarro J, de Hoog S, Hope W, Johnson E, Kathuria S, Lackner M, Lass-Florl C, Lortholary O, Meis JF, Meletiadis J, Munoz P, Richardson M, Roilides E, Tortorano AM, Ullmann AJ, van Diepeningen A, Verweij P, Petrikkos G. ESCMID and ECMM joint clinical guidelines for the diagnosis and management of mucormycosis 2013. Clin Microbiol Infect. 2014;20(Suppl 3):5-26. https://doi.org/10.1111/ 1469-0691.12371.

29. Cornely OA, Maertens J, Winston DJ, Perfect J, Ullmann AJ, Walsh TJ, Helfgott D, Holowiecki J, Stockelberg D, Goh YT, Petrini M, Hardalo C, Suresh R, Angulo-Gonzalez D. Posaconazole vs. fluconazole or itraconazole prophylaxis in patients with neutropenia. $\mathrm{N}$ Engl $\mathrm{J}$ Med. 2007;356(4):348-59. https://doi.org/10.1056/ NEJMoa061094.

30. Corp. MSD. Prevymis (letermovir) [package insert]. Whitehouse Station; 2017.

31. Crawford J, Becker PS, Armitage JO, Blayney DW, Chavez J, Curtin P, Dinner S, Fynan T, Gojo I, Griffiths EA, Hough S, Kloth DD, Kuter DJ, Lyman GH, Mably M, Mukherjee S, Patel S, Perez LE, Poust A, Rampal R, Roy V, Rugo HS, Saad AA, Schwartzberg LS, Shayani S, Talbott M, Vadhan-Raj S, Vasu S, Wadleigh M, Westervelt P, Burns JL, Pluchino L. Myeloid growth factors, Version 2.2017, NCCN Clinical Practice Guidelines in Oncology. J Natl Compr Cancer Netw. 2017;15(12):1520-41. https://doi.org/ 10.6004/jnccn.2017.0175.

32. Crothers K, Furrer H, Helweg-Larsen J, Huang L, Kovacs J, Miller R, Morris A (2017) Guidelines for the prevention and treatment of opportunistic infections in HIV-infected adults and adolescents: recommendations from the Centers for Disease Control and Prevention, the National Institutes of Health, and the HIV Medicine Association of the Infectious Diseases Society of America. Panel on Opportunistic Infections in HIV-Infected Adults and Adolescents. http://aidsinfo.nih.gov/contentfiles/ lvguidelines/adult_oi.pdf. Accessed 19 Apr 2018.
33. Cruciani M, Rampazzo R, Malena M, Lazzarini L, Todeschini G, Messori A, Concia E. Prophylaxis with fluoroquinolones for bacterial infections in neutropenic patients: a meta-analysis. Clin Infect Dis. 1996;23 (4):795-805.

34. Crumpacker C, Zhang J. Cytomegalovirus. In: Mandell G, Bennett J, Dolin R, editors. Mandell, Douglas, and Bennett's principles and practice of infectious diseases. 7th ed. Philadelphia: Elsevier; 2010. p. 1971-87.

35. Cutler C, Stevenson K, Kim HT, Richardson P, Ho VT, Linden E, Revta C, Ebert R, Warren D, Choi S, Koreth J, Armand P, Alyea E, Carter S, Horowitz M, Antin JH, Soiffer R. Sirolimus is associated with veno-occlusive disease of the liver after myeloablative allogeneic stem cell transplantation. Blood. 2008;112(12):4425-31. https://doi.org/ 10.1182/blood-2008-07-169342.

36. Dalle JH, Giralt SA. Hepatic veno-occlusive disease after hematopoietic stem cell transplantation: risk factors and stratification, prophylaxis, and treatment. Biol Blood Marrow Transplant. 2016;22(3):400-9. https://doi.org/10.1016/j.bbmt.2015.09.024.

37. Diri R, Anwer F, Yeager A, Krishnadasan R, McBride A. Retrospective review of intravenous pentamidine for Pneumocystis pneumonia prophylaxis in allogeneic hematopoietic stem cell transplantation. Transpl Infect Dis. 2016;18(1):63-9. https://doi.org/10.1111/ tid. 12486.

38. El Chaer F, Shah DP, Chemaly RF. How I treat resistant cytomegalovirus infection in hematopoietic cell transplantation recipients. Blood. 2016;128(23):2624-36. https://doi.org/10.1182/ blood-2016-06-688432.

39. Escuissato DL, Warszawiak D, Marchiori E. Differential diagnosis of diffuse alveolar haemorrhage in immunocompromised patients. Curr Opin Infect Dis. 2015;28(4):337-42. https://doi.org/ 10.1097/qco.0000000000000181.

40. Exela Pharma Sciences. Ganciclovir [package insert]. Lenoir; 2017.

41. Falci DR, Pasqualotto AC. Profile of isavuconazole and its potential in the treatment of severe invasive fungal infections. Infect Drug Resist. 2013;6:163-74. https://doi.org/10.2147/idr.S51340.

42. Foolad F, Aitken S, Shigle T. Use of oral ribavirin for the treatment of RSV Infections in Hematopoietic Cell Transplant Recipients. Paper presented at the ID Week; 2017.

43. Freifeld AG, Bow EJ, Sepkowitz KA, Boeckh MJ, Ito JI, Mullen CA, Raad II, Rolston KV, Young JA, Wingard JR. Clinical practice guideline for the use of antimicrobial agents in neutropenic patients with cancer: 2010 update by the infectious diseases society of america. Clin Infect Dis. 2011;52(4): e56-93. https://doi.org/10.1093/cid/cir073.

44. Fresenius Kabi. Decadron (dexamethasone sodium phosphate) [package insert]. Lake Zurich; 2014. 
45. Fukuda T, Hackman RC, Guthrie KA, Sandmaier BM, Boeckh M, Maris MB, Maloney DG, Deeg HJ, Martin PJ, Storb RF, Madtes DK. Risks and outcomes of idiopathic pneumonia syndrome after nonmyeloablative and conventional conditioning regimens for allogeneic hematopoietic stem cell transplantation. Blood. 2003;102(8):2777-85. https://doi.org/10.1182/blood2003-05-1597.

46. Galvin R, Brathen G, Ivashynka A, Hillbom M, Tanasescu R, Leone MA. EFNS guidelines for diagnosis, therapy and prevention of Wernicke encephalopathy. Eur J Neurol. 2010;17(12):1408-18. https:// doi.org/10.1111/j.1468-1331.2010.03153.x.

47. Garnacho-Montero J, Diaz-Martin A, Canton-BulnesL, Ramirez P, Sierra R, Arias-Verdu D, Rodriguez-Delgado M, Loza-Vazquez A, Rodriguez-Gomez J, Gordon M, Estella A, Garcia-Garmendia JL. Initial antifungal strategy reduces mortality in critically ill patients with candidemia: a propensity score-adjusted analysis of a multicenter study. Crit Care Med. 2018;46(3):384-93. https://doi.org/10.1097/ ccm.0000000000002867.

48. Genentech I. Actemra (tocilizumab) [package insert]. South San Francisco: Genentech, Inc; 2018.

49. Genentech USA I. Copegus (ribavirin) [package insert]. South San Francisco; 2011.

50. Gerber B, Guggenberger R, Fasler D, Nair G, Manz MG, Stussi G, Schanz U. Reversible skeletal disease and high fluoride serum levels in hematologic patients receiving voriconazole. Blood. 2012;120(12):2390-4. https://doi.org/10.1182/blood2012-01-403030.

51. Gilbert D. Aminoglycosides. In: Mandell GLBJ, Dolin R, editors. Principles and practice of infectious diseases. 5th ed. New York: Churchill Livingston; 2000. p. 307-35.

52. Gilead Sciences I. Tamiflu (oseltamivir phosphate) [package insert]. Foster City; 2008.

53. Gilead Sciences I. Vistide (cidofovir injection) [package insert]. Foster City; 2010.

54. GlaxoSmithKline. Zovirax (acyclovir) [package insert]. Research Triangle Park; 2003.

55. Goldner W. Cancer-related hypercalcemia. J Oncol Pract. 2016;12(5):426-32. https://doi.org/10.1200/ jop.2016.011155.

56. Greenberg RN, Mullane K, van Burik JA, Raad I, Abzug MJ, Anstead G, Herbrecht R, Langston A, Marr KA, Schiller G, Schuster M, Wingard JR, Gonzalez CE, Revankar SG, Corcoran G, Kryscio RJ, Hare R. Posaconazole as salvage therapy for zygomycosis. Antimicrob Agents Chemother. 2006;50(1):126-33. https://doi.org/ 10.1128/aac.50.1.126-133.2006.

57. Grewal J, Grewal HK, Forman AD. Seizures and epilepsy in cancer: etiologies, evaluation, and management. Curr Oncol Rep. 2008;10(1):63-71.

58. Gupta SK, Kantesaria B, Glue P. Pharmacokinetics, safety, and tolerability of ribavirin in hemodialysisdependent patients. Eur J Clin Pharmacol.
2012;68(4):415-8. https://doi.org/10.1007/s00228011-1137-X

59. Gupta SK, Kantesaria B, Glue P. Pharmacokinetics and safety of single-dose ribavirin in patients with chronic renal impairment. Drug Discov Ther. 2013;7 (4):158-63.

60. Gupta SK, Kantesaria B, Glue P. Exploring the influence of renal dysfunction on the pharmacokinetics of ribavirin after oral and intravenous dosing. Drug Discoveries \& Therapeutics. 2014;8(2):89-95.

61. Hamadani M, Awan F. Role of thiamine in managing ifosfamide-induced encephalopathy. J Oncol Pharm Pract. 2006;12(4):237-9. https://doi.org/10.1177/ 1078155206073553.

62. Hankerson MJ, Raffetto B, Mallon WK, Shoenberger JM. Nebulized tranexamic acid as a noninvasive therapy for cancer-related hemoptysis. J Palliat Med. 2015;18(12):1060-2. https://doi.org/ 10.1089/jpm.2015.0167.

63. Holly P, Lisa L, Plamenova I, Dobrotova M, Kubisz P. Recombinant activated factor VII as an additional agent in the management of bleeding in patients with chemotherapy-induced thrombocytopenia. Blood transfus. 2013;11 (3):466-8. https://doi.org/10.2450/2012.0077-12.

64. Hospira Inc. Amicar (aminocaproic acid) [package insert]. Lake Forest; 2017.

65. Howard SC, McCormick J, Pui CH, Buddington RK, Harvey RD. Preventing and managing toxicities of high-dose methotrexate. Oncologist. 2016;21(12):1471-82. https://doi.org/10.1634/ theoncologist.2015-0164.

66. Imbach P, Crowther M. Thrombopoietin-receptor agonists for primary immune thrombocytopenia. N Engl J Med. 2011;365(8):734-41. https://doi.org/ 10.1056/NEJMct1014202.

67. Jaksic B, Martinelli G, Perez-Oteyza J, Hartman CS, Leonard LB, Tack KJ. Efficacy and safety of linezolid compared with vancomycin in a randomized, doubleblind study of febrile neutropenic patients with cancer. Clin Infect Dis. 2006;42(5):597-607. https:// doi.org/10.1086/500139.

68. Janssen Biotech I. Sylvant (siltuximab) [package insert]. Horsham; 2017.

69. Jazz Pharmaceuticals I. Defitelio (defibrotide) [package insert]. Palo Alto; 2016.

70. Kantrow SP, Hackman RC, Boeckh M, Myerson D, Crawford SW. Idiopathic pneumonia syndrome: changing spectrum of lung injury after marrow transplantation. Transplantation. 1997;63(8):1079-86.

71. Kim S-H, Kwon J-C, Choi S-M, Lee D-G, Park SH, Choi J-H, Yoo J-H, Cho B-S, Eom K-S, Kim Y-J, Kim H-J, Lee S, Min C-K, Cho S-G, Kim D-W, Lee J-W, Min W-S. Escherichia coli and Klebsiella pneumoniae bacteremia in patients with neutropenic fever: factors associated with extended-spectrum $\beta$-lactamase production and its impact on outcome. Ann Hematol. 2013;92(4):533-41. https://doi.org/ 10.1007/s00277-012-1631-y.

72. Kostakou E, Rovina N, Kyriakopoulou M, Koulouris NG, Koutsoukou A. Critically ill cancer 
patient in intensive care unit: issues that arise. J Crit Care. 2014;29(5):817-22. https://doi.org/10.1016/j. jerc.2014.04.007.

73. Kuo SH, Debnam JM, Fuller GN, de Groot J. Wernicke's encephalopathy: an underrecognized and reversible cause of confusional state in cancer patients. Oncology. 2009;76(1):10-8. https://doi.org/10.1159/000174951.

74. Kuter DJ. Thrombopoietin and thrombopoietin mimetics in the treatment of thrombocytopenia. Annu Rev Med. 2009;60:193-206.

75. Kuter DJ. Managing thrombocytopenia associated with cancer chemotherapy. Oncology (Williston Park). 2015;29(4):282-94.

76. Kuter DJ, Bussel JB, Lyons RM, Pullarkat V, Gernsheimer TB, Senecal FM, Aledort LM, George JN, Kessler CM, Sanz MA, Liebman HA, Slovick FT, de Wolf JT, Bourgeois E, Guthrie TH Jr, Newland A, Wasser JS, Hamburg SI, Grande C, Lefrere F, Lichtin AE, Tarantino MD, Terebelo HR, Viallard JF, Cuevas FJ, Go RS, Henry DH, Redner RL, Rice L, Schipperus MR, Guo DM, Nichol JL. Efficacy of romiplostim in patients with chronic immune thrombocytopenic purpura: a double-blind randomised controlled trial. Lancet (London, England). 2008;371(9610):395-403. https://doi.org/10.1016/s0140-6736(08)60203-2.

77. Lara AR, Schwarz MI. Diffuse alveolar hemorrhage. Chest. 2010;137(5):1164-71. https://doi.org/ 10.1378/chest.08-2084.

78. Leibovici L, Paul M, Cullen M, Bucaneve G, Gafter-Gvili A, Fraser A, Kern WV. Antibiotic prophylaxis in neutropenic patients: new evidence, practical decisions. Cancer. 2006;107(8):1743-51. https://doi.org/10.1002/cncr.22205.

79. Lewis ID, DeFor T, Weisdorf DJ. Increasing incidence of diffuse alveolar hemorrhage following allogeneic bone marrow transplantation: cryptic etiology and uncertain therapy. Bone Marrow Transplant. 2000;26(5):539-43. https://doi.org/10.1038/sj. bmt. 1702546.

80. Lindemans CA, Leen AM, Boelens JJ. How I treat adenovirus in hematopoietic stem cell transplant recipients. Blood. 2010;116(25):5476-85. https:// doi.org/10.1182/blood-2010-04-259291.

81. Loblaw DA, Perry J, Chambers A, Laperriere NJ. Systematic review of the diagnosis and management of malignant extradural spinal cord compression: the Cancer Care Ontario Practice Guidelines Initiative's Neuro-Oncology Disease Site Group. J Clin Oncol. 2005;23(9):2028-37. https:// doi.org/10.1200/jco.2005.00.067.

82. Ltd. CH. Foscavir (foscarnet sodium) [package insert]. DE14 2WW, UK; 2011.

83. Marshall AL, Goodarzi K, Kuter DJ. Romiplostim in the management of the thrombocytopenic surgical patient. Transfusion. 2015;55(10):2505-10. https:// doi.org/10.1111/trf.13181.

84. Marty FM, Ljungman P, Chemaly RF, Maertens J, Dadwal SS, Duarte RF, Haider S, Ullmann AJ, Katayama Y, Brown J, Mullane KM, Boeckh M,
Blumberg EA, Einsele H, Snydman DR, Kanda Y, DiNubile MJ, Teal VL, Wan H, Murata Y, Kartsonis NA, Leavitt RY, Badshah C. Letermovir prophylaxis for cytomegalovirus in hematopoietic-cell transplantation. N Engl J Med. 2017;377(25):2433-44. https://doi.org/10.1056/NEJMoa1706640.

85. Metcalf JP, Rennard SI, Reed EC, Haire WD, Sisson JH, Walter T, Robbins RA. Corticosteroids as adjunctive therapy for diffuse alveolar hemorrhage associated with bone marrow transplantation. University of Nebraska Medical Center Bone Marrow Transplant Group. Am J Med. 1994;96(4):327-34.

86. Miao J, Leblebjian H, Fowler-Scullion B, Parnes A. Single-center experience with Romiplostim for management of chemotherapy-induced thrombocytopenia (CIT). Blood. 2016;128:530.

87. Mielcarek M, Furlong T, Storer BE, Green ML, McDonald GB, Carpenter PA, Flowers ME, Storb R, Boeckh M, Martin PJ. Effectiveness and safety of lower dose prednisone for initial treatment of acute graft-versus-host disease: a randomized controlled trial. Haematologica. 2015;100(6):842-8. https://doi.org/10.3324/haematol.2014.118471.

88. Mintzer S, Mattson RT. Should enzyme-inducing antiepileptic drugs be considered first-line agents? Epilepsia. 2009;50(Suppl 8):42-50. https://doi.org/ 10.1111/j.1528-1167.2009.02235.x.

89. Moore RD, Lietman PS, Smith CR. Clinical response to aminoglycoside therapy: importance of the ratio of peak concentration to minimal inhibitory concentration. J Infect Dis. 1987;155(1):93-9.

90. Mylan Institutional LLC. Miacalcin (calcitonin) [product insert]. Rockford; 2016.

91. Neelapu SS, Tummala S, Kebriaei P, Wierda W, Gutierrez C, Locke FL, Komanduri KV, Lin Y, Jain N, Daver N, Westin J, Gulbis AM, Loghin ME, de Groot JF, Adkins S, Davis SE, Rezvani K, Hwu P, Shpall EJ. Chimeric antigen receptor T-cell therapy assessment and management of toxicities. Nat Rev Clin Oncol. 2018;15(1):47-62. https://doi.org/ 10.1038/nrclinonc.2017.148.

92. Nicolau DP, Freeman CD, Belliveau PP, Nightingale $\mathrm{CH}$, Ross JW, Quintiliani R. Experience with a oncedaily aminoglycoside program administered to 2,184 adult patients. Antimicrob Agents Chemother. 1995;39(3):650-5.

93. Novartis Pharmaceuticals Corporation. Sandimmune (cyclosporine capsules, oral solution, injection) [package insert]. East Hanover; 2015.

94. Novartis Pharmaceuticals Corporation. Zometa (zoledronic acid) [package insert]. East Hanover; 2016.

95. Novo Nordisk Inc. NovoSeven (coagulation factor VIIa) [package insert]. Princeton; 2006.

96. Ojeda E, Carca-Marco JA, Navarro B, Delalglesia A, Fores R, Bautista G, Krsnik I, Sanchez-Guerrero A, Sanjuan I, Regidor C, Gonzalo-Daganzo R, Martin-Donaire T, Sanchez R, Bravo G, Claros N, Cabero M, Beltran P, Cabrera JR. Use of romiplostim 
to facilitate platelet engraftment in allogeneic hematopoietic transplantation. Blood. 2011;118:1947.

97. Pagkalis S, Mantadakis E, Mavros MN, Ammari C, Falagas ME. Pharmacological considerations for the proper clinical use of aminoglycosides. Drugs. 2011;71(17):2277-94. https://doi.org/10.2165/ 11597020-000000000-00000.

98. Pappas PG, Kauffman CA, Andes DR, Clancy CJ, Marr KA, Ostrosky-Zeichner L, Reboli AC, Schuster MG, Vazquez JA, Walsh TJ, Zaoutis TE, Sobel JD. Clinical Practice Guideline for the Management of Candidiasis: 2016 update by the Infectious Diseases Society of America. Clin Infect Dis. 2016;62(4):e1-50. https://doi.org/10.1093/cid/ civ933.

99. Paquette F, Bernier-Jean A, Brunette V, Ammann H, Lavergne V, Pichette V, Troyanov S, Bouchard J. Acute kidney injury and renal recovery with the use of aminoglycosides: a large retrospective study. Nephron. 2015;131(3):153-60. https://doi.org/10.1159/000440867.

100. Pathak V, Kuhn J, Gabriel D, Barrow J, Jennette JC, Henke DC. Use of activated factor VII in patients with diffuse alveolar hemorrhage: a 10 years institutional experience. Lung. 2015;193(3):375-9. https:// doi.org/10.1007/s00408-015-9720-z.

101. Patterson TF, Thompson GR 3rd, Denning DW, Fishman JA, Hadley S, Herbrecht R, Kontoyiannis DP, Marr KA, Morrison VA, Nguyen MH, Segal BH, Steinbach WJ, Stevens DA, Walsh TJ, Wingard JR, Young JA, Bennett JE. Practice guidelines for the diagnosis and management of aspergillosis: 2016 update by the Infectious Diseases Society of America. Clin Infect Dis. 2016;63(4):e1-e60. https://doi.org/ 10.1093/cid/ciw326.

102. Paul M, Yahav D, Fraser A, Leibovici L. Empirical antibiotic monotherapy for febrile neutropenia: systematic review and meta-analysis of randomized controlled trials. J Antimicrob Chemother. 2006;57(2):176-89. https://doi.org/10.1093/jac/ dki448.

103. Pelgrims J, De Vos F, Van den Brande J, Schrijvers D, Prove A, Vermorken JB. Methylene blue in the treatment and prevention of ifosfamide-induced encephalopathy: report of 12 cases and a review of the literature. Br J Cancer. 2000;82(2):291-4. https:// doi.org/10.1054/bjoc.1999.0917.

104. Pennington CA, Park JM. Sublingual tacrolimus as an alternative to oral administration for solid organ transplant recipients. Am J Health Syst Pharm. 2015;72(4):277-84. https://doi.org/10.2146/ ajhp140322.

105. Pfizer. Cyklokapron (tranexamic acid) [package insert]. New York; 2011a.

106. Pfizer. Solu-Medrol (methylprednisolone sodium succinate for injection) [package insert]. New York; $2011 b$.

107. Pfizer. Zinecard (dexrazoxane for injection) [package insert]. New York; 2012.

108. Pfizer Inc. Rapamune (sirolimus) [package insert]. Philadelphia; 2011.
109. Pharmacia \& Upjohn Co. Zyvox (linezolid) [package insert]. New York; 2018.

110. Posteraro B, De Pascale G, Tumbarello M, Torelli R, Pennisi MA, Bello G, Maviglia R, Fadda G, Sanguinetti M, Antonelli M. Early diagnosis of candidemia in intensive care unit patients with sepsis: a prospective comparison of $(1->3)$-beta-D-glucan assay, Candida score, and colonization index. Crit Care. 2011;15(5):R249. https://doi.org/10.1186/ cc10507.

111. Radigan EA, Gilchrist NA, Miller MA. Management of aminoglycosides in the intensive care unit. $\mathrm{J}$ Intensive Care Med. 2010;25(6):327-42. https://doi. org/10.1177/0885066610377968.

112. Raptis A, Mavroudis D, Suffredini A, Molldrem J, Rhee FV, Childs R, Phang S, Barrett A. High-dose corticosteroid therapy for diffuse alveolar hemorrhage in allogeneic bone marrow stem cell transplant recipients. Bone Marrow Transplant. 1999;24(8):879-83. https://doi.org/10.1038/sj. bmt. 1701995 .

113. Rathi NK, Tanner AR, Dinh A, Dong W, Feng L, Ensor J, Wallace SK, Haque SA, Rondon G, Price KJ, Popat U, Nates JL. Low-, mediumand high-dose steroids with or without aminocaproic acid in adult hematopoietic SCT patients with diffuse alveolar hemorrhage. Bone Marrow Transplant. 2015;50(3):420-6. https://doi.org/ 10.1038/bmt.2014.287.

114. Rhodes A, Evans LE, Alhazzani W, Levy MM, Antonelli M, Ferrer R, Kumar A, Sevransky JE, Sprung CL, Nunnally ME, Rochwerg B, Rubenfeld GD, Angus DC, Annane D, Beale RJ, Bellinghan GJ, Bernard GR, Chiche JD, Coopersmith C, De Backer DP, French CJ, Fujishima S, Gerlach H, Hidalgo JL, Hollenberg SM, Jones AE, Karnad DR, Kleinpell RM, Koh Y, Lisboa TC, Machado FR, Marini JJ, Marshall JC, Mazuski JE, McIntyre LA, McLean AS, Mehta S, Moreno RP, Myburgh J, Navalesi P, Nishida O, Osborn TM, Perner A, Plunkett CM, Ranieri M, Schorr CA, Seckel MA, Seymour CW, Shieh L, Shukri KA, Simpson SQ, Singer M, Thompson BT, Townsend SR, Van der Poll T, Vincent JL, Wiersinga WJ, Zimmerman JL, Dellinger RP. Surviving Sepsis Campaign: International guidelines for management of sepsis and septic shock: 2016. Crit Care Med. 2017;45(3):486-552. https://doi.org/10.1097/ccm.0000000000002255.

115. Richards A, Marshall H, McQuary A. Evaluation of methylene blue, thiamine, and/or albumin in the prevention of ifosfamide-related neurotoxicity. J Oncol Pharm Pract. 2011;17(4):372-80. https:// doi.org/10.1177/1078155210385159.

116. Richardson PG, Ho VT, Giralt S, Arai S, Mineishi S, Cutler C, Antin JH, Stavitzski N, Niederwieser D, Holler E, Carreras E, Soiffer R. Safety and efficacy of defibrotide for the treatment of severe hepatic veno-occlusive disease. Ther Adv Hematol. 2012;3(4):253-65. https://doi.org/10.1177/ 2040620712441943. 
117. Richardson PG, Riches ML, Kernan NA, Brochstein JA, Mineishi S, Termuhlen AM, Arai S, Grupp SA, Guinan EC, Martin PL, Steinbach G, Krishnan A, Nemecek ER, Giralt S, Rodriguez T, Duerst R, Doyle J, Antin JH, Smith A, Lehmann L, Champlin R, Gillio A, Bajwa R, D'Agostino RB Sr, Massaro J, Warren D, Miloslavsky M, Hume RL, Iacobelli M, Nejadnik B, Hannah AL, Soiffer RJ. Phase 3 trial of defibrotide for the treatment of severe veno-occlusive disease and multi-organ failure. Blood. 2016;127(13):1656-65. https://doi.org/ 10.1182/blood-2015-10-676924.

118. Roberts I, Coats T, Edwards P, Gilmore I, Jairath V, Ker K, Manno D, Shakur H, Stanworth S, Veitch A. HALT-IT-tranexamic acid for the treatment of gastrointestinal bleeding: study protocol for a randomised controlled trial. Trials. 2014;15:450. https://doi.org/10.1186/1745-6215-15-450.

119. Rybak JM, Marx KR, Nishimoto AT, Rogers PD. Isavuconazole: pharmacology, pharmacodynamics, and current clinical experience with a new triazole antifungal agent. Pharmacotherapy. 2015;35(11):1037-51. https://doi.org/10.1002/ phar. 1652.

120. Sandherr M, Maschmeyer G. Pharmacology and metabolism of voriconazole and Posaconazole in the treatment of invasive aspergillosis: review of the literature. Eur J Med Res. 2011;16(4):139-44.

121. Sanofi-Aventis. Elitek (rasburicase) [package insert]. Bridgewater; 2017.

122. Santabarbara G, Maione P, Rossi A, Gridelli C. Pharmacotherapeutic options for treating adverse effects of Cisplatin chemotherapy. Expert Opin Pharmacother. 2016;17(4):561-70. https://doi. org/10.1517/14656566.2016.1122757.

123. Segrelles Calvo G, De Granda-Orive I, Lopez Padilla D. Inhaled tranexamic acid as an alternative for hemoptysis treatment. Chest. 2016;149(2):604. https://doi.org/10.1016/j.chest.2015.10.016.

124. Shimabukuro-Vornhagen A, Boll B, Kochanek M, Azoulay E, von Bergwelt-Baildon MS. Critical care of patients with cancer. CA Cancer J Clin. 2016; https://doi.org/10.3322/caac.21351.

125. Skiada A, Lanternier F, Groll AH, Pagano L, Zimmerli S, Herbrecht R, Lortholary O, Petrikkos GL. Diagnosis and treatment of mucormycosis in patients with hematological malignancies: guidelines from the 3rd European Conference on Infections in Leukemia (ECIL 3). Haematologica. 2013;98(4):492-504. https://doi.org/10.3324/ haematol.2012.065110.

126. Smith PF, Birmingham MC, Noskin GA, Meagher AK, Forrest A, Rayner CR, Schentag JJ. Safety, efficacy and pharmacokinetics of linezolid for treatment of resistant Gram-positive infections in cancer patients with neutropenia. Ann Oncol. 2003;14(5):795-801.

127. Smith TJ, Bohlke K, Lyman GH, Carson KR, Crawford J, Cross SJ, Goldberg JM,
Khatcheressian JL, Leighl NB, Perkins CL, Somlo G, Wade JL, Wozniak AJ, Armitage JO. Recommendations for the use of WBC growth factors: American Society of Clinical Oncology Clinical Practice Guideline update. J Clin Oncol. 2015;33(28):3199-212. https://doi.org/10.1200/ jco.2015.62.3488.

128. Soff GA, Miao Y, Devlin SM, Mantha S, Mones JV, Li VJ, Abou-Alfa GK, Cercek A, Kemeny N, Parameswara R. Romiplostim for chemotherapy-induced thrombcytopenia (CIT). Results of a phase 2 trial. Blood. 2017;130:289.

129. Soubani AO, Pandya CM. The spectrum of noninfectious pulmonary complications following hematopoietic stem cell transplantation. Hematol Oncol Stem Cell Ther. 2010;3(3):143-57.

130. Staras SA, Dollard SC, Radford KW, Flanders WD, Pass RF, Cannon MJ. Seroprevalence of cytomegalovirus infection in the United States, 1988-1994. Clin Infect Dis. 2006;43(9):1143-51. https://doi.org/ 10.1086/508173.

131. Steinberg A, Gorman E, Tannenbaum J. Thiamine deficiency in stem cell transplant patients: a case series with an accompanying review of the literature. Clin Lymphoma Myeloma Leuk. 2014;14(Suppl): S111-3. https://doi.org/10.1016/j.clml.2014.06.009.

132. Stewart AF. Clinical practice. Hypercalcemia associated with cancer. N Engl J Med. 2005;352(4):373-9. https://doi.org/10.1056/NEJMcp042806.

133. Tang Y, Wu Q, Wu X, Qiu H, Sun A, Ruan C, Wu D, Han Y. Use of recombinant factor VIIa in uncontrolled gastrointestinal bleeding after hematopoietic stem cell transplantation among patients with thrombocytopenia. Pak J Med Sci. 2015;31(6):1389-93. https://doi.org/10.12669/ pjms.316.8357.

134. Thachil J, Falanga A, Levi M, Liebman H, Di Nisio M. Management of cancer-associated disseminated intravascular coagulation: guidance from the SSC of the ISTH. J Thromb Haemost. 2015;13(4):671-5. https://doi.org/10.1111/jth.12838.

135. Tizon R, Frey N, Heitjan DF, Tan KS, Goldstein SC, Hexner EO, Loren A, Luger SM, Reshef R, Tsai D, Vogl D, Davis J, Vozniak M, Fuchs B, Stadtmauer EA, Porter DL. High-dose corticosteroids with or without etanercept for the treatment of idiopathic pneumonia syndrome after allo-SCT. Bone Marrow Transplant. 2012;47(10):1332-7. https://doi.org/ 10.1038/bmt.2011.260.

136. Tomblyn M, Chiller T, Einsele H, Gress R, Sepkowitz K, Storek J, Wingard JR, Young J-A, Boeckh MJ. Guidelines for preventing infectious complications among hematopoietic cell transplant recipients: a global perspective. Bone Marrow Transplant. 2009;44(8):453-558.

137. Turner RB, Cumpston A, Sweet M, Briggs F, Slain D, Wen S, Craig M, Hamadani M, Petros W. Prospective, controlled study of acyclovir pharmacokinetics in obese patients. Antimicrob Agents 
Chemother. 2016;60(3):1830-3. https://doi.org/ 10.1128/aac.02010-15.

138. UCB I. Keppra (levetiracetam) [package insert]. Smyrna; 2017.

139. Ullmann AJ, Lipton JH, Vesole DH, Chandrasekar P, Langston A, Tarantolo SR, Greinix H, Morais de Azevedo W, Reddy V, Boparai N, Pedicone L, Patino H, Durrant S. Posaconazole or fluconazole for prophylaxis in severe graft-versus-host disease. N Engl J Med. 2007;356(4):335-47. https://doi.org/ 10.1056/NEJMoa061098.

140. Van Lint MT, Uderzo C, Locasciulli A, Majolino I, Scime R, Locatelli F, Giorgiani G, Arcese W, Iori AP, Falda M, Bosi A, Miniero R, Alessandrino P, Dini G, Rotoli B, Bacigalupo A. Early treatment of acute graft-versus-host disease with high- or low-dose 6-methylprednisolone: a multicenter randomized trial from the Italian Group for Bone Marrow Transplantation. Blood. 1998;92(7):2288-93.

141. Vecht CJ, Haaxma-Reiche H, van Putten WL, de Visser M, Vries EP, Twijnstra A. Initial bolus of conventional versus high-dose dexamethasone in metastatic spinal cord compression. Neurology. 1989;39(9):1255-7.

142. Vecht CJ, van Breemen M. Optimizing therapy of seizures in patients with brain tumors. Neurology. 2006;67(12 Suppl 4):S10-3.

143. Wanko SO, Broadwater G, Folz RJ, Chao NJ. Diffuse alveolar hemorrhage: retrospective review of clinical outcome in allogeneic transplant recipients treated with aminocaproic acid. Biol Blood Marrow Transplant. 2006;12(9):949-53. https://doi.org/10.1016/j. bbmt.2006.05.012.
144. West-Ward Pharmaceuticals. Allopurinol [package insert]. Eatontown; 2015.

145. Wilson DT, Dimondi VP, Johnson SW, Jones TM, Drew RH. Role of isavuconazole in the treatment of invasive fungal infections. Ther Clin Risk Manag. 2016;12:1197-206. https://doi.org/10.2147/tcrm. S90335.

146. Wingard JR, Carter SL, Walsh TJ, Kurtzberg J, Small TN, Baden LR, Gersten ID, Mendizabal AM, Leather HL, Confer DL, Maziarz RT, Stadtmauer EA, Bolanos-Meade J, Brown J, Dipersio JF, Boeckh M, Marr KA. Randomized, double-blind trial of fluconazole versus voriconazole for prevention of invasive fungal infection after allogeneic hematopoietic cell transplantation. Blood. 2010;116(24):5111-8. https://doi.org/10.1182/blood-2010-02-268151.

147. Winter M. Basic and clinical pharmacokinetics. 5th ed. Philadelphia: Lippincott Williams and Wilkins; 2010. p. 263-70.

148. Woo M, Przepiorka D, Ippoliti C, Warkentin D, Khouri I, Fritsche H, Korbling M. Toxicities of tacrolimus and cyclosporin A after allogeneic blood stem cell transplantation. Bone Marrow Transplant. 1997;20(12):1095-8. https://doi.org/ 10.1038/sj.bmt.1701027.

149. Zeiser R, Blazar BR. Acute graft-versus-host disease - biologic process, prevention, and therapy. N Engl J Med. 2017;377(22):2167-79. https://doi.org/ 10.1056/NEJMra1609337.

150. Juhl RC, Roddy JVF, Wang TF, Li J, Elefritz JL (2018) Thromboembolic complications following aminocaproic acid use in patients with hematologic malignancies. Leukemia \& lymphoma:1-6. https:// doi.org/10.1080/10428194.2018.1434882. 